Review

\title{
Bioreactor design for enzymatic hydrolysis of biomass under the biorefinery concept
}

\author{
Marcela Sofía Pino ${ }^{a}$, Rosa M. Rodríguez-Jasso ${ }^{\mathrm{a}, \mathrm{b}}$, Michele Michelin ${ }^{\mathrm{c}}$, Adriana C. Flores-Gallegos ${ }^{\mathrm{a}}$, \\ Ricardo Morales-Rodriguez ${ }^{\mathrm{b}, \mathrm{d}}$, José A. Teixeira ${ }^{\mathrm{c}}$, Héctor A. Ruiz ${ }^{\mathrm{a}, \mathrm{b}, *}$

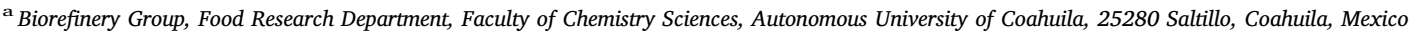 \\ ${ }^{\mathrm{b}}$ Cluster of Bioalcohols, Mexican Centre for Innovation in Bioenergy (Cemie-Bio), Mexico \\ ${ }^{c}$ CEB-Centre of Biological Engineering, University of Minho, Campus Gualtar, 4710-057 Braga, Portugal \\ d Departamento de Ingeniería Química, Universidad de Guanajuato, 36050 Guanajuato, Mexico
}

\section{H I G H L I G H T S}

- Enzymatic hydrolysis (EH) bioreactors must include adequate and optimal design.

- Stirred tank and membrane bioreactors are the most commonly units used in $\mathrm{EH}$.

- The use of high solid loadings as alternative to improve EH processes.

- Bubble column and gas-lift bioreactors are promising configurations for $\mathrm{EH}$.

\section{A R T I C L E I N F O}

\section{Keywords:}

Enzymatic hydrolysis

Bioreactor design

Stirred tank

Membrane

Bubble column

Gas-lift

\section{G R A P H I C A L A B S T R A C T}

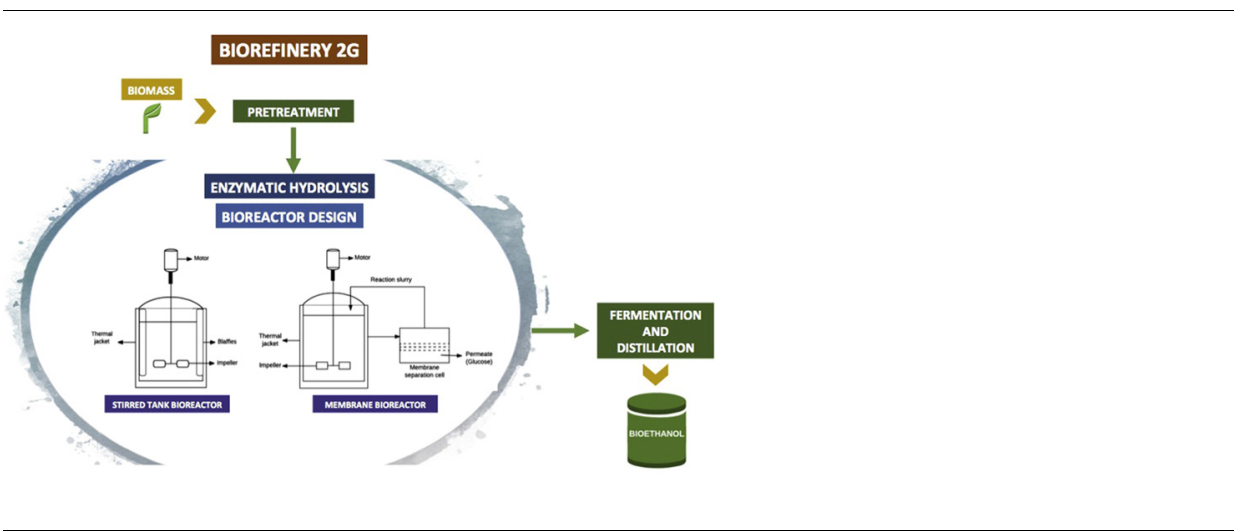

\begin{abstract}
A B S T R A C T
The dependence on non-renewable resources, particularly fossil fuels, has awaken a growing interest in research of sustainable alternative energy sources, such as bioethanol. The production of bioethanol from lignocellulosic materials comprises three main stages, starting with a pretreatment, followed by an enzymatic hydrolysis step where fermentable sugars are obtained for the final fermentation process. Enzymatic hydrolysis represents an essential step in the bioethanol production, however there are some limitations in it that hinders the process to be economically feasible. Different strategies have been studied to overcome these limitations, including the enzyme recycling and the utilization of high solids concentrations. Several investigations have been carried out in different bioreactor configurations with the aim to obtain higher yields of glucose in the enzymatic hydrolysis stage; however, the commonest are Stirred Tank Bioreactors (STBR) and Membrane Bioreactors (MBR). In general, the key criteria for a bioreactor design include adequate mass transfer, low shear stress, and efficient mixing that allows the appropriated interaction between the substrate and the enzyme. Therefore, this review will address the main aspects to be considered for a bioreactor design, as well as, the operational conditions, some characteristics and mode of operating strategies of the two main bioreactors used in the enzymatic hydrolysis stage. Moreover, two types of pneumatically agitated bioreactors, namely bubble column and gas-lift bioreactors, are discussed as promising alternatives to develop enzymatic saccharification due to their low energy consumption compared with STBR.
\end{abstract}

* Corresponding author at: Biorefinery Group, Food Research Department, Faculty of Chemistry Sciences, Autonomous University of Coahuila, Blvd. V. Carranza e Ing. José Cárdenas Valdés, 25280 Saltillo, Coahuila, Mexico.

E-mail address: hector_ruiz_leza@uadec.edu.mx (H.A. Ruiz). 


\section{Nomenclature}

A

constant for gas hold-up in bubble column reactors ( $\mathrm{A}=0.277$ for water and aqueous solutions of glycerol and glycol, and $\mathrm{A}=0.364$ for aqueous solutions of inorganic electrolytes) (-)

$A_{d} \quad$ downcomer cross-sectional area $\left(\mathrm{m}^{2}\right)$

$A_{i} \quad$ effective pore area for solute transport $\left(\AA^{2}\right)$

$A_{p} \quad$ total pore area of the membrane $\left(\AA^{2}\right)$

$A_{r} \quad$ riser cross-sectional area $\left(\mathrm{m}^{2}\right)$

$A_{w} \quad$ area available for water transport $\left(\AA^{2}\right)$

$b \quad$ friction coefficient (-)

$B \quad$ concentration of cellobiose in the reactor $\left(\mathrm{kg} \mathrm{m}^{-3}\right)$

$C^{*} \quad$ saturation concentration of dissolved oxygen $\left(\mathrm{kg} \mathrm{m}^{-3}\right)$

$C_{0} \quad$ initial concentration of dissolved oxygen $\left(\mathrm{kg} \mathrm{m}^{-3}\right)$

$C$ concentration of cellulose in the reactor $\left(\mathrm{kg} \mathrm{m}^{-3}\right)$

$C_{L} \quad$ concentration of dissolved oxygen $\left(\mathrm{kg} \mathrm{m}^{-3}\right)$

$C_{p} \quad$ concentration of respective components in the permeate flow (g/L)

$C_{r} \quad$ concentration respective components in the retentate inside the reactor $(\mathrm{g} / \mathrm{L})$

$C_{S} \quad$ average solid concentration gas free-slurry $\left(\mathrm{kg} \mathrm{m}^{-3}\right)$

$c_{t} \quad$ constant calculated theoretically with values between 0.75 and $2(-)$

$D_{A B} \quad$ liquid phase diffusivity $\left(\mathrm{m}^{2} \mathrm{~s}^{-1}\right)$

$D_{B} \quad$ bioreactor diameter (m)

$D_{c} \quad$ column diameter (m)

$D_{i} \quad$ diffusion coefficient for a solute's component $\left(\mathrm{cm}^{2} \mathrm{~s}^{-1}\right)$

$D_{I} \quad$ diameter of the impeller (m)

$F_{B} \quad$ mass flow rate of cellobiose $\left(\mathrm{kg} \mathrm{h}^{-1}\right)$

$F_{C} \quad$ mass flow rate of cellulose $\left(\mathrm{kg} \mathrm{h}^{-1}\right)$

$F_{C i} \quad$ mass flow rate of the total amount of inlet cellulose $\left(\mathrm{kg} \mathrm{h}^{-1}\right)$

$F_{G} \quad$ mass flow rate of glucose $\left(\mathrm{kg} \mathrm{h}^{-1}\right)$

$F_{P G} \quad$ mass flow rate of glucose through the membrane $\left(\mathrm{kg} \mathrm{h}^{-1}\right)$

$\mathrm{Fr}_{\mathrm{g}} \quad$ Froude Number at the gas (-)

$F \eta \quad$ Froude Number at the liquid (-)

$g \quad$ gravitational acceleration $\left(\mathrm{m} \mathrm{s}^{-2}\right)$

$G \quad$ concentration of glucose in the reactor $\left(\mathrm{kg} \mathrm{m}^{-3}\right)$

$G_{a} \quad$ Galileo number (-)

$G_{p} \quad$ concentration of glucose in the permeate $\left(\mathrm{kg} \mathrm{m}^{-3}\right)$

$h_{a l} \quad$ height of aerated liquid (m)

$H_{B} \quad$ height of the liquid (m)

$h_{D} \quad$ dispersion height (m)

$H_{I} \quad$ height of the impellers (m)

$h_{o l} \quad$ height of the original liquid (m)

$J_{v} \quad$ volumetric flow per unit of membrane area $\left(\mathrm{cm} \mathrm{s}^{-1}\right)$

$K$ distribution factor between pore fluid and bulk solution $(-)$

$k_{1} \quad$ rate constant of conversion of cellulose to cellobiose $\left(\mathrm{h}^{-1}\right)$

$K_{1 B} \quad$ inhibition constant of cellobiose on reaction of conversion of cellulose to cellobiose $\left(\mathrm{kg} \mathrm{m}^{-3}\right)$

$K_{1 G} \quad$ inhibition constant of glucose on reaction of conversion of cellulose to cellobiose $\left(\mathrm{kg} \mathrm{m}^{-3}\right)$ $k_{2}$

$K_{2 G}$

$K_{B}$

$k_{L} a$

$K_{m}$

$K_{m p}$

$K_{T}$

$L_{I}$

$N_{I}$

$N_{S}$

$N_{P}$

$N_{R e}$

$P_{G}$

$P_{W}$

R

$r_{1}$

$r_{2}$

$T$

$t$ inhibition constant of conversion of cellobiose to glucose $\left(\mathrm{kg} \mathrm{m}^{-3} \mathrm{~h}^{-1}\right)$

inhibition constant of glucose on reaction of conversion of cellobiose to glucose $\left(\mathrm{kg} \mathrm{m}^{-3}\right)$

frictional loss coefficient at the bottom (-)

volumetric mass transfer coefficient $\left(\mathrm{s}^{-1}\right)$

Michaelis Menten constant $\left(\mathrm{kg} \mathrm{m}^{-3}\right)$

mass transfer coefficient of the membrane $\left(\mathrm{m}^{3} \mathrm{~h}^{-1}\right)$

frictional loss coefficient at the top (-)

length of the impellers (m)

impeller speed (rps)

normal stress $\left(\mathrm{N} \mathrm{m}^{-2}\right)$

Power number (-)

Reynolds number (-)

power input due to gas (W)

power consumption (W)

rejection coefficient in membrane bioreactors (-)

rate of conversion of cellulose to cellobiose $\left(\mathrm{kg} \mathrm{m}^{-3} \mathrm{~h}^{-1}\right)$

rate of conversion of cellobiose to glucose $\left(\mathrm{kg} \mathrm{m}^{-3} \mathrm{~h}^{-1}\right)$

temperature $\left({ }^{\circ} \mathrm{C}\right)$

time (s)

electrode response time (s)

mixing time (s)

tortuosity factor $(-)$

torque of the impeller $(\mathrm{N} \mathrm{m})$

terminal bubble rise velocity $\left(\mathrm{m} \mathrm{s}^{-1}\right)$

riser gas velocity $\left(\mathrm{m} \mathrm{s}^{-1}\right)$

average bubble velocity $\left(\mathrm{m} \mathrm{s}^{-1}\right)$

superficial gas velocity $\left(\mathrm{m} \mathrm{s}^{-1}\right)$

superficial liquid velocity $\left(\mathrm{m} \mathrm{s}^{-1}\right)$

volume of liquid $\left(\mathrm{m}^{3}\right)$

volume of the membrane bioreactor $\left(\mathrm{m}^{3}\right)$

width of baffles (m)

width of impellers (m)

conversion of inlet cellulose into glucose (-)

ethanol concentration in oleic acid $(\mathrm{g} / \mathrm{L})$

fractional pore area of the membrane $(-)$

downcomer gas holdup (-)

overall gas holdup (-)

riser gas holdup (-)

volume fraction of solids in gas-free slurry phase (-)

fouling layer real thickness $(\mathrm{cm})$

kinematic viscosity of liquid $\left(\mathrm{m}^{2} \mathrm{~s}^{-1}\right)$

viscosity of liquid phase ( $\mathrm{Pa} \mathrm{s}$ )

fluid density $\left(\mathrm{kg} \mathrm{m}^{-3}\right)$

liquid density $\left(\mathrm{kg} \mathrm{m}^{-3}\right)$

solid density $\left(\mathrm{kg} \mathrm{m}^{-3}\right)$

liquid surface tension $\left(\mathrm{N} \mathrm{m}^{-1}\right)$

shear stress $(\mathrm{Pa})$

mixing time factor $(-)$

angular velocity of the impeller ( $\operatorname{rad~s}^{-1}$ )

pressure gradient along column height $\left(\mathrm{Pa} \mathrm{m}^{-1}\right)$

\section{Introduction}

A growing interest in research involving renewable energy resources has been observed in the last decades, due to the depletion of fossil fuels and the environmental concerns, specifically global warming $[1,2]$.

To overcome those issues, many alternatives have been developed, including the use of these resources through a biorefinery, which is a technology that aims to produce bioenergy and high value-added products, such as biofuels, based on the concept of today's petroleum refinery. Biorefinery involves a sequence of environmentally friendly processes that employs biomass as raw material, representing a renewable source of energy [3-6].

Biofuels have been explored as an alternative to reduce the dependence on petroleum. Biofuels are obtained from biomass through chemical, physical, or biological processes. They present several advantages such as easy availability, clean processing, biodegradability, and contribution to sustainable development. Worldwide, one of the 
most important liquid biofuels used in transportation is bioethanol, which consists in an alcohol obtained from sugar and starchy materials that has been considered a promising substitute or partial substitute of fossil fuels. It has a high octane number (108) and has the advantage of being able to be used in vehicles engines $[1,2,7,8]$.

However, a limiting step in the biofuels production is enzymatic hydrolysis, where the high cost of enzymes and the production of inhibitors of enzymatic activity and fermentation microorganisms limit the viability of the production of biofuels through biomass. In this context, the design of the bioreactor is an important tool to be explored in order to overcome these limitations. The optimization of the design of the bioreactor allows to control some parameters that play a fundamental role in the effectiveness of the enzymatic hydrolysis, such as mixing efficiency and, mass and heat transfer.

Thus, this review focuses on the enzymatic hydrolysis step of the bioethanol production process and on the equipment required for its performance, including the most commonly used bioreactor configurations in enzymatic saccharification, the operational conditions, and operating strategies, as well as the main aspects to be considered for their design. Firstly, an overview of the biofuel production process is given, including the pretreatment, general aspects of enzymatic hydrolysis, and fermentation, as well as some types of biomass used for the bioethanol production; in the end an approach is taken on the promising enzymatic hydrolysis bioreactors for the future.

\subsection{Raw material}

There are different types of feedstock that can be employed in the production process of biofuels. These have been divided into three generations.

Worldwide, first-generation biofuels are the most common. The production of this type of biofuels is based on food or energetic crops, particularly corn, wheat, and sugar cane [9]. However, although these crops represent a renewable alternative source of energy to fossil fuels, they have the disadvantage of raising the agricultural lands occupancy and reducing the area for food production, leading to an increase in global food prices and creating a competition between food and energy supply $[10,11]$.

The development of second-generation biofuels emerged as a response to overcome the food versus energy conflict. Lately, interest in them has grown widely because they represent a promising sustainable alternative to substitute petroleum energy and diminish the negative environmental impact [4]. Second generation biofuels are produced from a diversity of lignocellulosic biomasses, including industrial, agricultural and forestry residues, as well as non-edible crops. These types of raw materials are renewable low-priced, and accessible [9,11-14].

Lignocellulosic materials are mainly composed of cellulose, hemicellulose and lignin polymers that are present in the cell wall of plants. These polymers interact with each other and provide the material a recalcitrant nature due to cellulose crystallinity and the linkage through covalent and hydrogen bonds $[15,16]$. Cellulose and hemicellulose can be reduced to fermentable sugars to produce bioethanol. A typical composition of lignocellulosic biomass consists of $35-50 \%$ cellulose, $15-35 \%$ hemicellulose and $10-35 \%$ lignin. However, the concentration of the components depends mainly on the source of the plant studied $[12,17]$.

On the other hand, third generation biofuels are obtained from aquatic biomass such as macro and micro algae, as well as fish residues [17-19]. Third generation biofuels present certain advantages over first and second biofuels, such is the case of microalgae which harvesting cycle is shorter than traditional crops, allowing higher yields due to several harvests through the year $[20,21]$.

\subsection{Second-generation bioethanol production process}

The production process of bioethanol from lignocellulosic biomass involves three main stages: pretreatment, enzymatic hydrolysis, and fermentation. Fig. 1 presents a flow diagram of the production process of second-generation bioethanol.

\subsubsection{Pretreatment}

First, the raw material must be subjected to a pretreatment, which is an essential step in the process to overcome the recalcitrance of the lignocellulosic biomass. Pretreatment consists in the fractionation of the biomass into its main components (cellulose, hemicellulose, and lignin) to facilitate the subsequent enzymatic and microbial attack. Pretreatment facilitates the access to biomass by reducing the crystallinity of cellulose, increasing the pore size and surface area of cellulose, modifying the lignin structure, and totally or partially solubilizing hemicellulose. A diversity of pretreatment methods has been developed, including physical, physicochemical, chemical and biological processes [2,12,22-24].

Physical pretreatment consists in the comminution of the lignocellulosic biomass with the aim to reduce the particle size and the crystallinity of the biomass by mechanical methods such as milling, grinding or chipping [25-27]. On the other hand, chemical pretreatment implies the utilization of different chemical compounds to disrupt the lignocellulosic structure. They are classified according to their chemical nature as acid, alkaline and ionic liquid pretreatments. Also, oxidizing agents can be used to chemically pretreat the biomass, including ozonolysis and peroxide oxidative pretreatment; as well as organic solvents in an organosolv pretreatment $[26,28]$. Furthermore, a diversity of physical and chemical technologies combinations have been used to reduce the recalcitrance of the lignocellulosic biomass. The most commonly used physicochemical strategies are liquid hot water (also known as autohydrolysis), steam explosion, ammonia fibre explosion and, microwave pretreatment $[25,29,30]$. Finally, biological pretreatments represent an environmentally friendly alternative that comprises the use of microorganisms, mainly fungi, that produces enzymes able to degrade lignin and hemicellulose [25,26,31].

\subsubsection{Enzymatic hydrolysis}

Once the biomass has been subjected to a pretreatment, the second stage in the production of bioethanol is the hydrolysis of the polysaccharides recovered from the pretreatment. Hydrolysis consists in the degradation of the polysaccharides in an aqueous medium catalyzed by enzyme or acid. Therefore, the hydrolysis can be carried out by chemical or enzymatic processes $[2,17]$. However, enzymatic hydrolysis is considered the most promising strategy because it presents several

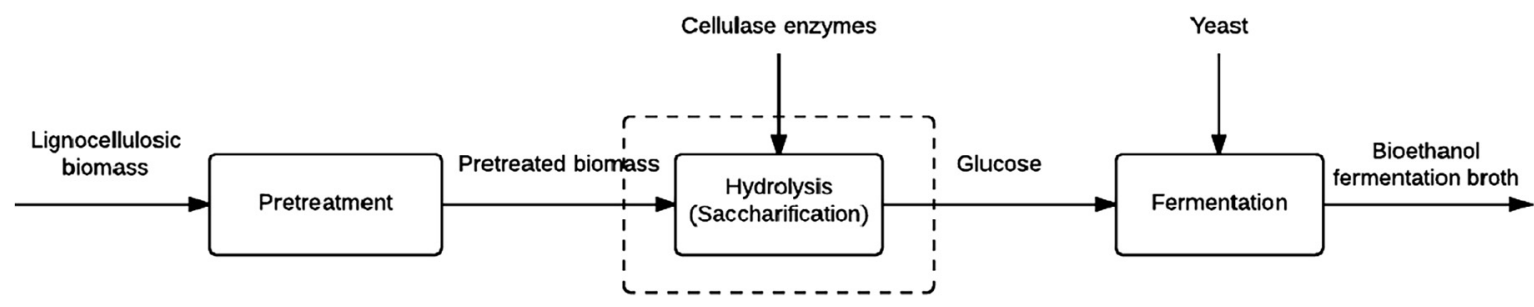

Fig. 1. Production process of second-generation bioethanol. 
advantages over chemical saccharification including high efficiency, low energy consumption due to the requirement of mild operation conditions, not environmental damage because enzymes are biodegradable, not toxic compounds formation and, low deterioration and corrosion problems for the equipment. Additionally, enzymatic hydrolysis produces fewer fermentation inhibitors [12,32-36].

1.2.2.1. Cellulase action mechanism. Enzymatic hydrolysis of cellulose involves the reaction between cellulases and insoluble cellulose in an aqueous medium that aims at the degradation of polysaccharides into fermentable monomeric sugars $[1,33,37]$. So, in this process, cellulolytic enzymes are used as catalysts to cleave $\beta-1,4$ glucosidic bonds present in cellulose to generate glucose that subsequently can be transformed into bioethanol by fermentation. Cellulase enzymes are a complex system of highly specific proteins that comprise three main types: endo-1,4- $\beta$-D-glucanases, exo-1,4- $\beta$-D-glucanases (also known as cellobiohydrolases) and $\beta$-glucosidase. This group of enzymes works synergistically to degrade cellulose molecule. First of all, endoglucanases randomly break down $\beta-1,4$ glucosidic bonds in the amorphous regions in the interior of cellulose backbone releasing mainly cellodextrin by the addition of a water molecule in the $\beta-1,4$ glucosidic linkage, producing new reducing and non-reducing ends. Subsequently, cellodextrin is hydrolyzed by the action of exoglucanases. So, exoglucanases hydrolyzes cellulose and these cellodextrins from its reducing and non-reducing chain ends to produce cellobiose (dimer conformed by two units of glucose); and finally, $\beta$-glucosidases cleave cellobiose releasing soluble glucose monomers. $\beta$-Glucosidases does not have a significant effect over insoluble cellulose $[2,33,35,38-44]$. Fig. 2 shows the described mechanism of action of cellulase enzyme. Another important factor in the enzymatic reaction development is the adsorption of cellulases onto the surface of the lignocellulosic material. Most endoglucanases and exoglucanases have a carbohydrate binding module that promotes this adsorption process. Typically, adsorption has been reported to take between 10 and $15 \mathrm{~min}$, which is related to the reaction rate $[45,46]$.

The efficiency of cellulose enzymatic saccharification is determined by different factors. The optimal conditions for cellulolytic enzymes activity are temperature value between 45 and $55^{\circ} \mathrm{C}$ and $\mathrm{pH}$ in the range of 4-5 [15,25,33]. Also, mixing conditions and solid-liquid ratio play an essential role in the hydrolysis of the polymer because suitable mass and heat transfer are required to ensure a good enzyme-substrate interaction [47].

1.2.2.2. Enzymatic hydrolysis economics. Enzymatic saccharification has not been successful in the attempt to scale up the process to the industry due to several obstacles. Economically, enzymatic hydrolysis is considered commercially unfeasible due to the high cost of the cellulolytic enzymes $[2,17,48]$. Currently and according to Sigma Aldrich, the market price of the cellulases is approximately $\$ 9500$ USD/gal of enzyme [49]. However, Novozymes reported that their second generation cellulases, Cellic CTec $2^{\circledR}$, only represents a cost of $\$ 0.50$ USD/gal of ethanol produced [50]. According to Liu et al. [51], it is unfeasible to purchase cellulolytic enzymes from current market suppliers; therefore, the authors propose on-site enzyme production as an alternative to boost economically feasible industrial lignocellulosic ethanol production, which could lead to cellulase enzyme cost reduction from 30 to $70 \%$ [51-53]. The cost of cellulases is still difficult to certainly stablish, because it depends on several factors, including enzyme dosage and the bioethanol production yield, as well as, negotiation between suppliers and consumer [51,54]. The cost contribution of enzymes has been reported to vary from \$0.1 USD to $\$ 0.4$ USD per gallon of bioethanol produced [54-56]. However, KleinMarcuschamer et al. [55], in their techno-economic model for the production of bioethanol from corn stover, reported a cellulase enzyme cost $\$ 0.68 \mathrm{USD} /$ gal ethanol assuming the maximum theoretical yields in the process, and an enzyme price of $\$ 1.47 \mathrm{USD} / \mathrm{gal}$ using previously reported yields. In a more recent techno economical evaluation, Liu et al. [51] found an enzyme cost of $\$ 2.71 \mathrm{USD} / \mathrm{gal}$ based on the commercial price of enzyme and conventional yields of bioethanol. Moreover, it has been reported that the enzyme cost represents about $15-28 \%$ of the bioethanol selling price, or $20 \%$ of the overall bioethanol production costs $[45,53,57,58]$. Therefore, enzyme cost is considered one of the main barriers that hinder the commercialization of second generation bioethanol [59].

Additionally, enzymatic hydrolysis undergoes other limitations, including the slow rate of the hydrolysis reaction that is related to the decrease in cellulase activity, due to the inhibition of the enzyme by several compounds present during the saccharification process [34]. The presence of xylan (major component of hemicellulose) and lignin in the biomass reduces the efficiency of hydrolysis, because they act as a physical barrier that prevents the access of the enzyme to the cellulose surface. Particularly, lignin is an important inhibitor due to the high affinity of cellulase to it, so that the enzyme tends to adsorb into lignin's surface generating non-productive binding that reduces the enzymes activity [47,60-62]. Moreover, during the pretreatment, a wide variety of inhibitors are produced, such as phenolic compounds, furfural, 5hydroxymetil furfural (HMF), weak acids, among others. However, the type and amount of inhibitors generated depend on the type of pretreatment employed $[35,40,41]$.

The crystallinity of cellulose and polymerization degree are also

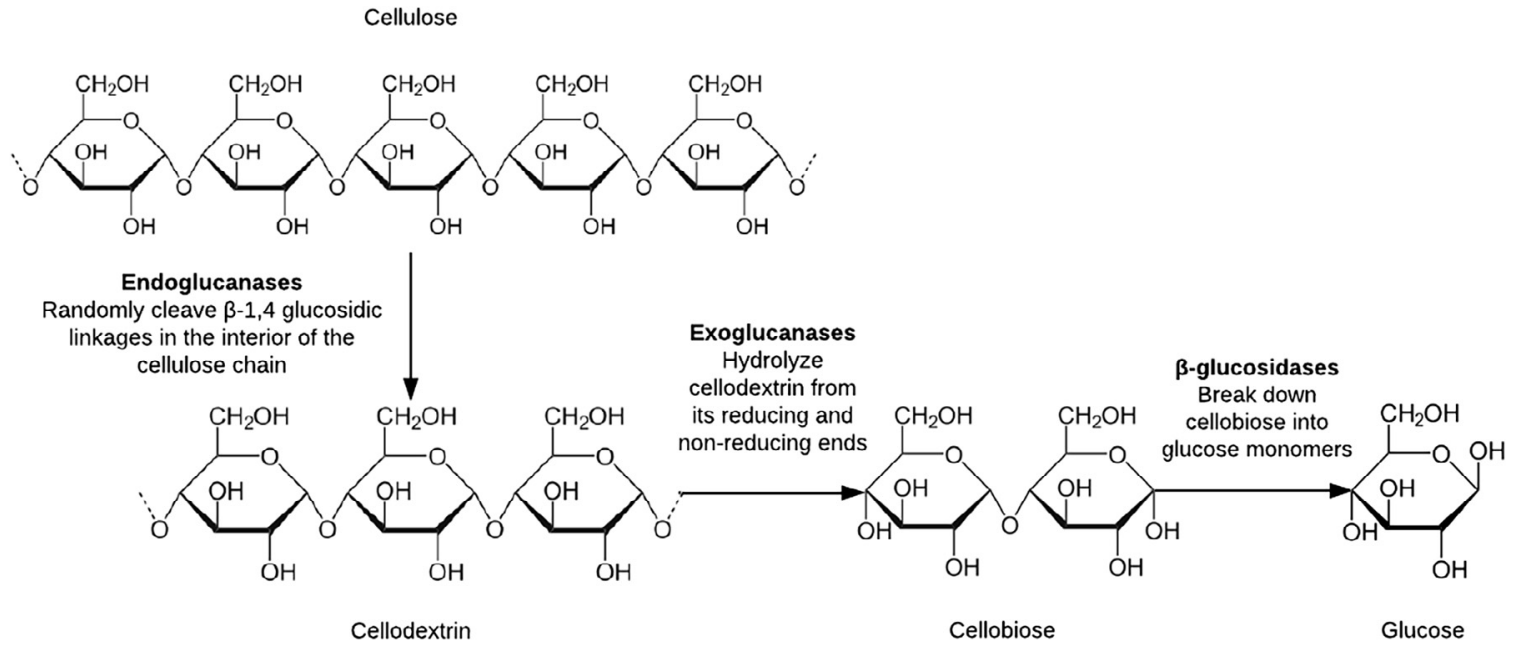

Fig. 2. Cellulase enzymes action mechanism. Modified and adapted from Aditiya et al. [2]. 
obstacles that hinder the action of enzyme action and diminish the glucose production yield $[2,37]$. Furthermore, during the enzymatic hydrolysis, oligosaccharides, disaccharides, and monosaccharides are produced which also act as inhibitors of cellulase enzyme. It has been demonstrated that these enzymes undergo feedback inhibition, as in the case of cellobiose that can inhibit cellulase. Likewise, $\beta$-glucosidase generally has its activity reduced in the presence of glucose $[38,41,63,64]$.

Consequently, a diversity of strategies has been proposed to improve the cellulose bioconversion into glucose in the enzymatic saccharification process, with the aim to make it more efficient and costeffective. In previous studies, percentages of $40-50 \%$ of cellulases have been reported to stay absorbed onto lignin surface after saccharification processes, which represents economic losses due to decreased glucose yields $[45,59]$. As a result of this difficulty, one of the strategies developed consists in the addition of surfactants or non-catalytic proteins to prevent the non-productive binding of the cellulolytic enzymes to lignin and thus decrease the deactivation of cellulases $[25,47,65,66]$. Also, the production of more efficient cellulolytic enzymes with enhanced catalytic activity, the modification of the operational conditions, particularly the adjustment of the $\mathrm{pH}$, as well as the enzymes immobilization and recycling (see Section 2.3.1) are considered promising alternatives to increase the enzymatic hydrolysis yields [47,59,65-67]. Enzyme recycling is an option to reduce enzymatic bioconversion costs, as it allows to reuse cellulolytic enzymes for multiple lots, decreasing new enzyme feeding [68]. It has been stated that enzyme recycling could lead to enzyme cost savings reduction of 50-60\% [45]. Unfortunately, little information has been published and reported about enzyme recycling economics.

Another strategy to enhance the economics on enzymatic hydrolysis is the well-known simultaneous saccharification and fermentation (SSF), which consists in the integration of enzymatic and fermentative processes in a single step (see Section 1.2.3), as it reduces equipment, operation, and production costs. This alternative also allows to reduce feedback cellulase inhibition, as end products are promptly transformed into bioethanol making the process more efficient [69-71]. A technoeconomical evaluation carried out by Wingren et al. [72] indicated that the utilization of high solid loadings in SSF processes, the recycling of the process streams, as well as the reduction of yeast dosage could lead to significant economic improvements in bioethanol production.

Regarding to the strategies to overcome the economic limitations of the enzymatic hydrolysis, one of the most studied alternative is the employment of high solid concentrations. It is well documented that a cost-effective distillation process requires a concentration of ethanol over $4 \% \mathrm{w} / \mathrm{w}$, which implies that at least a concentration of $8 \% \mathrm{w} / \mathrm{w}$ of fermentable sugars should be achieved at the enzymatic hydrolysis stage $[1,64,73,74]$. Hence, to ensure an increased yield of glucose production, it is necessary to perform the saccharification with a high concentration of solids, specifically solid loadings above $15 \%$ on dry basis. However, a high concentration of solids may result in a highly viscous solution that may affect the mass and heat transfer between the enzyme and the substrate and produce an increased amount of inhibitory compounds. Many researches have been developed around these limitations with satisfactory results $[1,28,75]$.

\subsubsection{Fermentation}

The final stage in the production of bioethanol from lignocellulosic biomass is the fermentation, which consists in the conversion of monomeric sugars obtained in the enzymatic hydrolysis into bioethanol by the action of microorganisms such as yeast, bacteria, and fungi. The biological fermentation agents most commonly used for bioethanol production are yeasts, particularly Saccharomyces cerevisiae, which is capable of fermenting hexose sugars, especially glucose, in ethanol under controlled conditions $[2,40,76]$. Once the fermentation is completed, a subsequent purification step by distillation is required, where the produced bioethanol is separated from the water $[40,77]$.
Certain strategies have been developed to improve fermentation, including separate hydrolysis and fermentation (SHF) which consists in the execution of the enzymatic hydrolysis and fermentation in different stages. On the other hand, simultaneous saccharification and fermentation (SSF) performs the enzymatic hydrolysis and fermentation at the same time in a single reactor $[15,25,78-80]$. To meet desired overall yields during ethanol production from lignocellulosic materials, it is important to use both hexoses and pentoses. This can be achieved by cofermentation of sugars in SSF, so called SSCF (simultaneous saccharification and co-fermentation), using genetically modified yeast strains [81-83].

\section{Bioreactor design}

Bioreactors are essential elements in every biological process; even more they are considered the core of bioprocesses. Bioreactors are the units in which a reaction or a biological process occurs. The bioreactor must provide the optimal conditions to satisfy the requirements of the biological system (enzyme, microorganism or cell) and to ensure a high yield of the bioprocess $[84,85]$.

A bioreactor for the enzymatic saccharification stage must fulfill certain requirements. As mentioned in Section 1.2.2, the cost of enzymes represents an important limitation in the lignocellulosic biomass bioconversion for bioethanol production, therefore, the bioreactor aims to promote the conditions for maximum conversion of cellulose into glucose with the lowest dosage of enzyme. Then, the bioreactor must ensure the efficient use of the catalyst and the substrate, which will be reflected in the glucose yield produced per enzyme fed to the system and in the amount of glucose produced per cellulose unit, respectively, which are considered the main variables to be evaluated for the design of a bioreactor for the saccharification process. Additionally, the bioreactor design pretends to optimize the productive volume of the vessel, i.e. the rate of glucose production per volume of reactor [64].

The design of a bioprocess requires the prior study of the biological system involved, including aspects such as, the type of substrate to be transformed, and the conditions that potentiate the biological activity and improve the bioconversion to obtain a higher concentration of the desired product. In the specific case of enzymatic hydrolysis, it is necessary to determine the conditions that maximize the enzymatic activity $[84,86]$.

To design a bioreactor for the saccharification process, it is necessary to control certain parameters and variables, especially temperature, $\mathrm{pH}$, and agitation. The control of temperature and $\mathrm{pH}$ is essential to ensure the optimal conditions for the cellulolytic enzymes activity $[41,86]$. Additionally, an adequate mixture is fundamental to guarantee the optimal interaction between the cellulases and the substrate to favor the adsorption and the enzymes synergism, increasing the hydrolysis efficiency of the cellulose [65]. In the design of an enzymatic hydrolysis bioreactor is also essential to control mass and heat transfer conditions [87], as well as to evaluate the shear sensibility of the biological system, that is the degree of susceptibility to a shear force when applied excessive agitation, which may lead to a reduction in the enzyme activity $[84,86]$. Moreover, the energy consumption is a key factor to be considered in the bioreactor design to ensure the lowest power energy demand [88].

\subsection{Operation mode}

Regardless the bioreactor configuration and geometry, there are three main operation modes according to the way the substrate is fed, i.e. discontinuous, semi-continuous, and continuous mode. Fig. 3 graphically represents the behavior of the substrate concentration over time during a biological process in the different operational modes. The effect of the operation mode has been analyzed from the experimental and modelling point of view $[89,90]$. 


\subsubsection{Batch mode}

Discontinuous or batch mode is widely used in the production of bioethanol processes and it is the preferred one in several industries. In this operational mode, the substrate is initially loaded to the bioreactor without additional feed or removal of substances from the system (closed process). So, batch operation mode implies that the volume remains constant until the end of the reaction $[91,92]$.

\subsubsection{Fed-batch mode}

Also known as semi-continuous mode, this operational mode consists in the intermittent addition of nutrients during the enzymatic saccharification, so that at established periods of time, fresh substrate is added to the reaction vessel [91]. Fed-batch is considered a promising operational mode in biomass hydrolysis, because it promotes the homogenization of the biological system producing higher conversion yields than batch process [93,94]. Du et al. [95], reported that fedbatch mode represents an alternative to overcome mixing problems when working at high solids loads because it prevents the excessive viscosity of the substrate. Also, they stated that this operational mode allows increasing the initial substrate concentration and decreasing inhibition problems by reducing unproductive enzyme binding. Moreover, fed batch strategy provides longer time for the pretreated biomass to hydrolyze into fermentable sugars [1].

\subsubsection{Continuous mode}

In continuous mode processes, substrate is continuously fed to the bioreactor and the products are continuously removed from the reaction vessel with the same feed flow rate, so that, when the system reaches a certain steady state the volume of the liquid keeps constant through the biological reaction [85]. According to Al-Zuhair et al. [34], in processes affected by substrate inhibition, continuous biocatalytic reactions in stirred tank bioreactors are more convenient because they allow to minimize the substrate concentration. Additionally, it is stated that heat rate and temperature control are simpler in continuous mode reactors than in batch processes [96].

\subsection{Types of bioreactors}

In the last decades, different configurations of bioreactors have been developed to perform the enzymatic hydrolysis stage. The following paragraphs present a description of the most common bioreactors including their advantages and disadvantages, as well as the main aspects to keep in mind in each of the bioreactors types.

\subsubsection{Stirred tank bioreactors}

Stirred tank bioreactors (STBR) are the most commonly used to carry out enzymatic processes. This type of bioreactors consists of a cylindrical vessel with one or more impellers (agitators) assembled with an external motor. At batch mode, STBR assume that mixture is intense and uniform, so that operational conditions related to the biochemical reactions and the biocatalytic concentration are homogeneous inside the reactor. The design of these bioreactors can include baffles that prevent the generation of vortex and improve the mixing conditions between the substrate and the enzyme. To provide the heating-cooling interchange to the biological system, a diversity of techniques can be employed depending on the size of the bioreactor. For small scale reactors, the vessel can be placed into an incubator or equipped with an electrical heater. Also, the external wall of the vessel of small and large bioreactor can present a thermal jacket, this being the most commonly method used for large scale bioreactors. On the other hand, very large bioreactors are generally provided with internal serpentine heatingcooling systems $[85,97,98]$. Fig. 4(A) shows a schematic representation of a STBR with its principal components.

STBR could be built in of glass, stainless steel, or carbonate; however, laboratory scale bioreactors are usually built in glass. Fig. 4(B) presents a STBR with the principal dimensions that must be considered for the design of the unit. According to Garcia-Ochoa et al. [98], typically a 0.3-0.6 ratio is used for the diameter of the impeller and the diameter of the tank $\left(D_{I} / D_{B}\right)$. On the other hand, the proportion between the height of the bioreactor and the diameter of the bioreactor $\left(\mathrm{H}_{\mathrm{B}} / \mathrm{D}_{\mathrm{B}}\right)$ is stablished in a range of $2: 1$ or $3: 1$. Likewise, other typical ratios include $\mathrm{L}_{\mathrm{I}} / \mathrm{D}_{\mathrm{I}}: 0.25, \mathrm{~W}_{\mathrm{I}} / \mathrm{D}_{\mathrm{A}}: 0.2, \mathrm{H}_{\mathrm{I}} / \mathrm{D}_{\mathrm{A}}: 1$ and $\mathrm{W}_{\mathrm{F}} / \mathrm{D}_{\mathrm{B}}: 0.1$ [97].

2.2.1.1. Agitation systems. In order to ensure an adequate mass and heat transfer in a STBR during the enzymatic saccharification process, different types of agitation systems have been studied with the aim to enhance the cellulose conversion and reduce the power energy consumption.

The agitation system applies a force in the fluid that produces the movement and thus causes circulation, distribution, and interaction between the biological components. The mixing efficiency is determined by the rate, flow and, mixing patterns provided by the impellers. The mixing pattern can be classified as radial or axial, depending on the direction of movement of the components [85].

Most vessels are equipped with Rushton turbines, a radial flow impeller shown in Fig. 5(A). However, Rushton turbines have the disadvantage of creating a staged mixing pattern that produces an ununiform enzyme-substrate interaction, therefore, agitation systems that combine axial and radial impellers have recently been developed to achieve an enhanced mixing patterns [87]. Correâ et al. [99] employed three blade Elephant ear impellers (see Fig. 5(B)) in STBR to perform the enzymatic hydrolysis of sugarcane bagasse. They evaluated four dual-impeller configurations combining Rushton turbines and Elephant ear impellers and concluded that the configuration conformed by two Elephant ear impellers required lower energy consumption, less mixing time and presented better homogenization of the medium. Additionally,

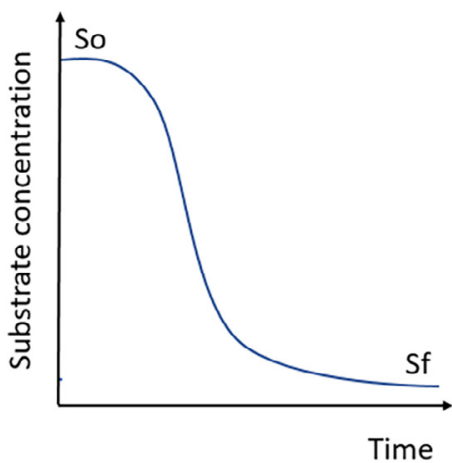

Batch

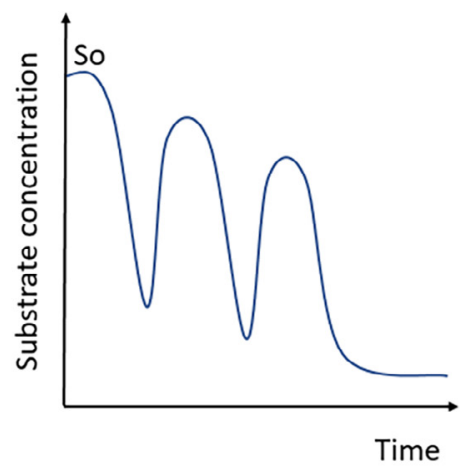

Fed-batch

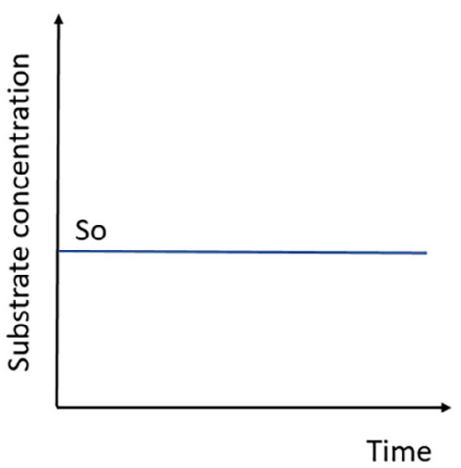

Continuous

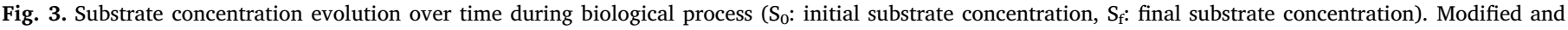
adapted from Teixeira et al. [85] 

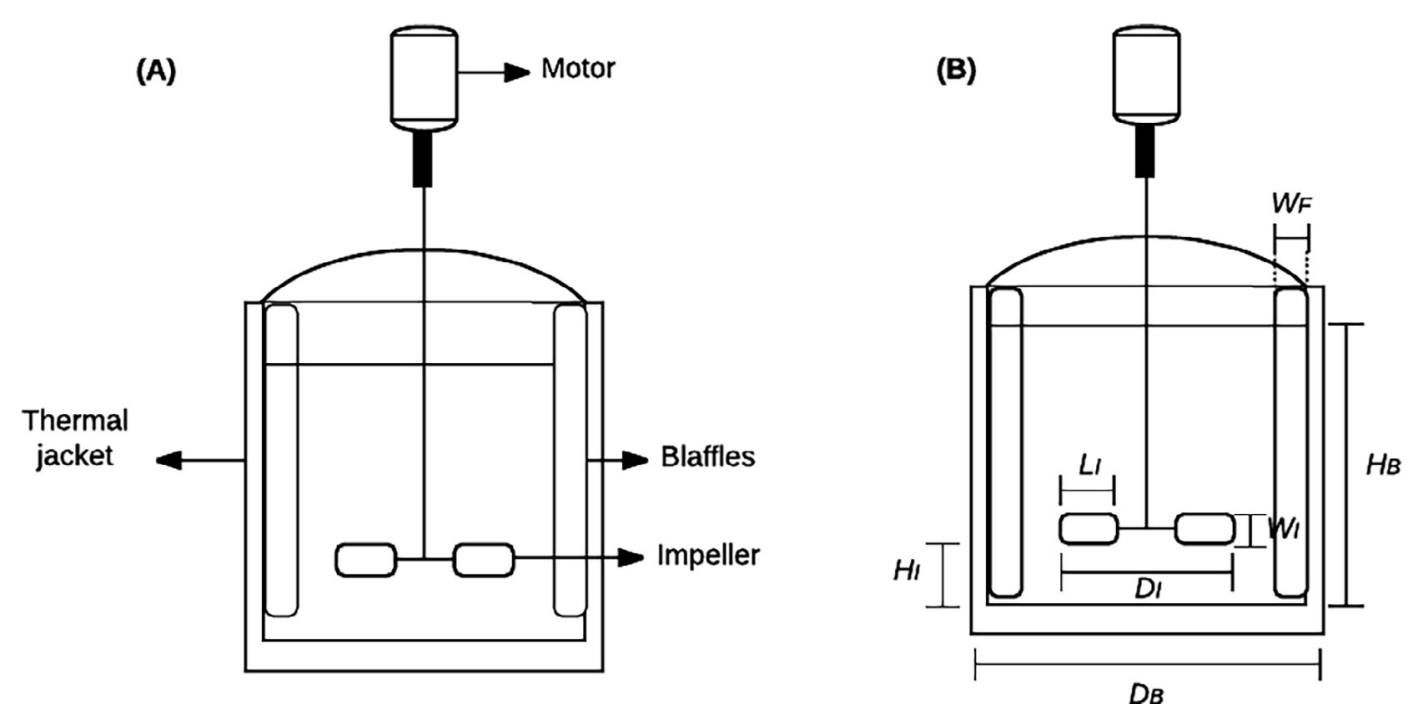

Fig. 4. (A) Stirred Tank Bioreactor schematic representation, (B) Nomenclature for STBR dimensioning $\left(W_{F}\right.$ : Width of baffles, $W_{I}$ : Width of the impeller, $D_{I}$ : Diameter of the impeller, $D_{B}$ : Diameter of the bioreactor, $H_{B}$ : Height of the bioreactor, $H_{I}$ : Height between the impellers and the bottom of the bioreactor, $L_{I}$ : Length of the impellers). Modified and adapted from Catapano et al. [97] and Garcia-Ochoa et al. [98].

elephant ear impeller diminished the effects of the soluble inhibitor compounds, producing a higher cellulose conversion [99]. On the other hand, Helical ribbon impellers illustrated in Fig. 5(C) are mainly used for non-Newtonian fluids and substrates with high viscosity that commonly would present difficulty at their agitation. This type of agitation systems has the advantage of providing an efficient mixing and requiring less energy consumption [65,100], which have turned them into a valuable alternative for enzymatic hydrolysis, developed at high solid loadings. Zhang et al. [88] designed a bioreactor with an agitation system formed by a Helical ribbon impeller to study a SSF at high solids loading for the production of bioethanol. In the research, a comparison between the Helical ribbon impeller and the commonly used Rushton turbine was made, identifying that Rushton turbine is not appropriate for high viscous fluids. The helically agitated system presented higher glucose yields and ethanol production rate than the Rushton turbine stirring, as well as energy conservation advantages [88].

Moreover, Fig. 5(D) shows another type of agitation system for enzymatic hydrolysis known as Peg mixer, which was employed by Caspeta et al. [101], who stated that Peg mixer is more convenient for enzymatic saccharification at high solid loadings, because it promotes
(A)

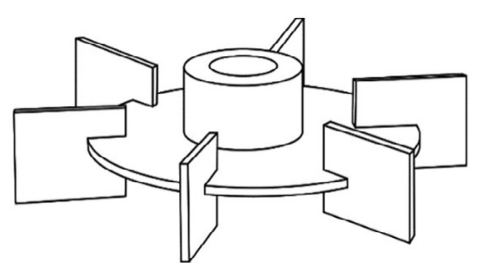

(B)

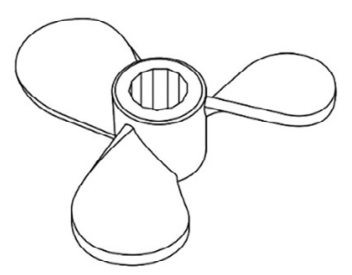

(C)

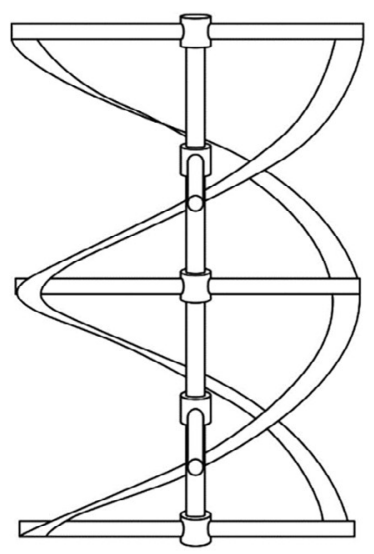

(D)

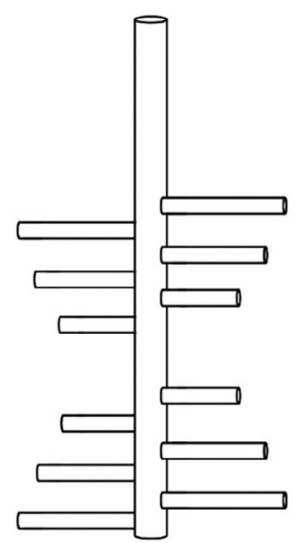

(E)

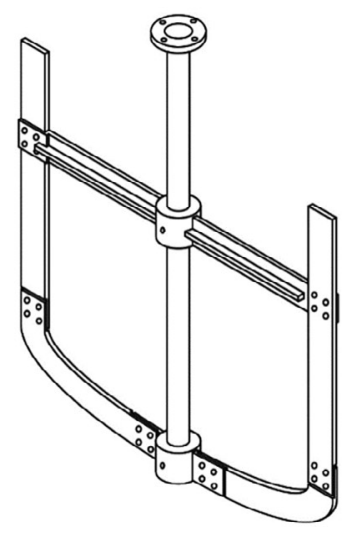

Fig. 5. Impeller types. (A) Rushton turbine, (B) Elephant ear impeller, (C) Helical ribbon impeller, (D) Peg mixer, (E) Anchor impeller. Modified and adapted from Garcia-Ochoa et al. [98] and Correâ et al. [99]. 
the absorption of the enzyme on the cellulose substrate. They studied the enzymatic bioconversion at high solid loadings in mini-bioreactors, reporting that this type of impeller allows to overcome the mass transfer limitations and enzyme inhibition commonly present in highly viscous fluids. The authors concluded that the experiments performed with the Peg mixer system presented higher conversion rates of cellulose to glucose than the ones developed in common shake flasks. Likewise, Fig. 5(E) depicts an Anchor impeller, which is a mixing configuration recommended for viscous fluids, because its blades work as scrapers that prevent stagnation of the material on the bioreactor walls [102]. Carvajal et al. [103] used a $5 \mathrm{~L}$ bioreactor with an anchor impeller to study the rheological properties variation of steam-exploded Arundo during enzymatic saccharification through computational fluid dynamics (CFD) software. The authors chose this mixing configuration to ensure that the slurry did not stick to the reactor walls and reported that the Anchor impeller presented good mixing performance over a wide range of conditions. In another research, Palmqvist et al. [104] studied enzymatic hydrolysis at high solid loadings using a 3 L STBR, equipped with an Anchor impeller to agitate the steam-pretreated material. In this research, two different aspects were evaluated; the first one consisted in keeping the impeller speed constant and the second one in maintaining the impeller power input constant during the enzymatic hydrolysis assays with two different raw materials (spruce and Arundo). The results showed that the behavior of the materials was different in both processes, therefore the researchers concluded that the design of the hydrolysis equipment and operation mode must be specific for each raw material, due to the different nature of the lignocellulosic materials evaluated.

There are different types of impellers that can be use in STBR during the enzymatic saccharification process. However, each one presents specific fluid profile, flow pattern and performance, therefore it is important to develop experimental assays to select the most suitable mixing configuration to guarantee an increased glucose yield [99].

2.2.1.2. Energy consumption. The cost-effectiveness of the enzymatic saccharification process implies ensuring a low energy consumption. Therefore, one of the most important variables to be taken into account in the STBR design is the energy consumption $\left(P_{W}\right)$, which is determined according to equation (1) $[65,85,105]$. Correâ et al. [99] applied equation (1) to determine the power number $\left(N_{P}\right)$ of a variety of impeller configurations to identify the most appropriate for the enzymatic hydrolysis of sugarcane. The power number is a variable that correlates the power consumption in an agitated vessel with the rotational speed and the physical properties of the medium [106]. In this investigation, the power consumption was estimated by the torque $\left(T_{q}\right)$ and the angular velocity $(\omega)$ of the agitators, as described in equation (2).

$P_{W}=N_{P} \rho_{F} N_{I}^{3} D_{A}^{5}$

$P_{W}=T_{q} \omega$

The power number $\left(N_{P}\right)$ is a characteristic constant of the agitator in a turbulent regimen. The equation (1) can be used to predict power consumption for fluids with Reynolds number $\left(N_{R e}\right)$ higher than $10^{4}$. A mathematical expression that allows to determine the flow regime of the fluid is the Reynolds number, which is defined as the expression presented in equation (3).

$N_{R e}=\rho_{F} N_{I} D_{I}^{2} / \mu_{l}$

2.2.1.3. Mixing time. Additionally, mixing time $\left(t_{m}\right)$ is an important variable to evaluate the performance of the mixing system in the STBR design. The mixing time is an specific variable of each bioprocess and correlates the reactor dimensions with the operating conditions of the system [99]. It represents a useful tool to scale-up the process [107]. Eqs. (4) and (5) present math expressions to estimate the mixing time for a STBR without aeration in turbulent regime ( $N_{R e}$ greater than 5000$)$ operated in a batch mode [108]. In equation (5), $c_{t}$ is a theoretically calculated constant with values between 0.75 and 2 [85].

$t_{m}=\frac{\left(D_{B} / D_{A}\right)^{3}\left(H_{L} / D_{B}\right)}{N_{I} N_{P}^{0.33}}$

$t_{m}=c_{t} \frac{\left(D_{B} / D_{A}\right)^{3}\left(H_{L} / D_{B}\right)}{N_{I}\left(N_{p}\left(H_{I} / D_{A}\right)^{2}\right)^{-0.33}}$

In an investigation carried out by Correâ et al. [99] to study the mixing design for enzymatic hydrolysis of sugarcane bagasse with different impeller configurations, the equation (6) was used to determinate the mixing time factor, as proposed by Norwood et al. [109], which is a dimensionless variable that can be plotted as a function of the Reynolds number to correlate the mixing and flow patterns.

$\varphi=\frac{t_{m}\left(N_{I} D_{A}^{2}\right)^{2 / 3} g^{1 / 6} D_{A}^{1 / 2}}{H_{L}^{1 / 2} D_{B}^{3 / 2}}$

\subsubsection{Membrane bioreactors}

Membrane bioreactors (MBR) are reactors that combine a biological reaction with a separation method. They employ specialized membranes that act as physical barriers, precluding the mobilization of the entire mass, and allowing the passage of one or more species. This configuration of bioreactor is considered a promising alternative to develop enzymatic hydrolysis. In cellulose saccharification, specific membranes allow the immobilization of the enzymes, which remain physically trapped in the membrane due to their impermeable nature $[84,110]$. The main advantage of this type of bioreactors is the possibility of recovering and reusing the biocatalyst. Also MBR present low shear stress forces that diminish the loss of the biocatalyst activity $[97,111]$.

As mentioned previously in Section 1.2.2, during the enzymatic hydrolysis of cellulose, cellulase enzyme undergoes feedback inhibition, mainly by glucose and cellobiose, which bind to the active site of the enzyme. According to Andrić et al. [64] the best method to minimize the inhibition by the product in the enzymatic hydrolysis of cellulose is the removal of the inhibitor product from the effluent of the reaction. Membrane separation methods have been reported to be cheaper and easier to scale up than chromatography processes [112]. Hence, the use of MBR has been stated as a promising alternative to reduce the feedback inhibition effect, in order to enhance cellulose conversion and improve enzyme efficiency. In this system, the enzyme and the polysaccharides (substrate) are impermeable to the membrane so that they are retained therein, whereas the glucose with a lower molecular weight permeates through the membrane $[111,113]$. Thus, Ohlson et al. [114] state that removal of end-products in MBR increases the initial reaction rate of enzymatic hydrolysis of cellulose by four times over conventional batch bioreactors results. Also, according to Gan et al. [115], the semi-continuous and continuous operations of MBR allow a greater cellulose conversion than batch processes due to feedback inhibition. Furthermore, Andrić et al. [113] remarked that the degree of cellulose conversion was $40 \%$ higher in MBR than the ones reached in batch reaction processes. Moreover, the MBR allowed the procurement of pure products due to the entrapment of the substrate and the enzyme in the semipermeable barrier [113].

In MBR, the biocatalyst can be used immobilized or free. The first configuration has been reported to be unfeasible for lignocellulosic substrates due to the limited adsorption of the enzyme on the solid substrate, which is essential for the bioconversion of cellulose to glucose by the cellulase action. However, the immobilized employment of the biocatalyst has the advantage of being able to reuse the enzyme as it remains trapped in the membrane. On the other hand, the utilization of the free enzyme presents higher degree of conversion of cellulose to glucose than the immobilized systems, because it allows a greater 
enzyme-substrate mass transfer, as well as in situ continuous product removal $[34,113]$.

2.2.2.1. System configuration. There are different configurations of bioreactors that employ membrane separation for removal of inhibitor product. Fig. 6(A) presents a typical representation of an integrated MBR, wherein a membrane is coupled to a STBR for the in situ removal of cellulose hydrolysate in the permeate, in the same container. This configuration is known as dead-end filtration, which refers to the use of a flow direction perpendicular to the membrane position. Dead-end filtration is the most commonly used configuration in integrated bioreactor systems [116]. Generally, in this system the reaction vessel is connected to substrate, enzyme, and buffer feed tanks as well as a product reservoir [117]. Carrying out the bioprocess in an integrated system exhibits certain benefits, such as the reduction of the operation costs and the capital investment, as well as conversion efficiency enhancement [115].

Another common configuration of the MBR consists on perform the saccharification in separated units, i.e. a mixing and saccharification tank and a separation unit, as shown in Fig. 6(B). In this case, firstly, the reaction is performed in a STBR and then it is transported to the membrane separation cell where glucose is permeated through the membrane. This configuration requires the recycling of the reaction slurry containing the biocatalyst $[113,118]$. The utilization of separated reaction tanks is simpler to scale up, however, it presents possible cellulase activity loss during its transport through pumping accessories [115].

Knutsen et al. [119] investigated the simultaneous implementation of two types of membrane technologies in the enzymatic saccharification of pretreated corn stover. They studied the recovery and reuse of cellulase enzyme, by using filter paper through a vacuum filtration unit to separate end products from substrate and enzyme particles; while the permeate was passed through an ultrafiltration cell to promote additional hydrolysis. The retentate was recycled to the reaction vessel in order to take advantage of the unhydrolyzed corn stover and, to reuse soluble enzyme contained in the filter cake. The results demonstrated that the additional ultrafiltration step is unfeasible due to highly linkage of the enzyme to the unhydrolyzed substrate. However, the authors stated that vacuum filtration with filter paper itself is an efficient technology to separate and reuse enzyme bound to the substrate. Table 1 presents a summary of some investigations that employed membrane systems to study enzymatic hydrolysis of cellulolytic substrates.

2.2.2.2. Operational variables. The operation of a MBR involves several parameters that should be taken into account, including reaction kinetics, mass transfer and product separation effectiveness [115].
Also, the operating temperature, $\mathrm{pH}$ and the concentration of the feed solution play an important role in the effectiveness of enzymatic hydrolysis in a bioreactor. However, these aspects were previously described in Section 1.2.2, therefore, the development of this section will focus on the first mentioned parameters.

The type of membrane is essential to ensure an efficient removal of the inhibitor products. Different types of separation units can be used in MBR for the purification of saccharides, including ultra- and nanofiltration membranes. Enzymes particle size vary from $10 \mathrm{kDa}$ to $100 \mathrm{kDa}$, so that ultrafiltration membranes (UFM) are suitable for their retention, as they encompass pore sizes from 0.5 to $100 \mathrm{kDa}$ [121]. UFM materials most commonly used for enzymatic MBR are ceramic and synthetic polymers, such as, nylon, polypropylene, polyethylene, polyamide, polysulfone, polyvinylidene difluoride, and cellulose acetate. Different factors should be considered in the selection of the most adequate membrane, including substrate, enzyme and end-product sizes, chemical interactions between the compounds involved in the reaction and separation [122,123]. However, specifically for cellulose hydrolysis, ultrafiltration membranes (UF) are the most frequently used, especially polysulfone membranes with a cut-off between 10 and $50 \mathrm{kDa}$, which are organic hydrophobic cellulosic barriers that are considered appropriate for use under mild conditions in which cellulolytic enzymes work best [116]. In the bioreactor, the membrane can be disposed either in tubular or flat-sheet membrane cells. Bélafi-Bakó et al. [111] compared the efficiency between a special UFM of layered tubular cell and the usual flat-sheet membrane module, finding out a $10 \%$ higher conversion of the substrate into product in the tubular unit, as well as, better productivity.

Regarding to the economy of MBR, it is considered that the membrane cost is one of the most significant investment in MBR. However, according to a recent economical evaluation developed by Abejón et al. [124], who studied the optimization of an enzymatic membrane bioreactor for wastewater treatment with ceramic membrane modules, the results indicated that the membrane cost represented from 0.1 to $4.8 \%$ of the annualized process total costs regarding to the regeneration frequency of the membrane; nevertheless, it was found that the most significant cost was due to operation of the MBR, representing 99.6 to $87.6 \%$ of the annualized process total costs. Otherwise, synthetic polymer membranes imply lower production costs than ceramic membranes [123]. López et al. [125] reported an ultrafiltration membrane cost of $\$ 1600$ USD, in agreement with the price considered by Bick et al. [126] in their economic evaluation of an integrated membrane system, who reported a cost of UFM modules of $\$ 1650$ USD.

Unfortunately, there is a common phenomenon called fouling that is considered one of the major drawbacks that affect the performance of MBR, due to permeate flux reduction, permeability, and membrane selectivity modification, as solids deposit and accumulate on the
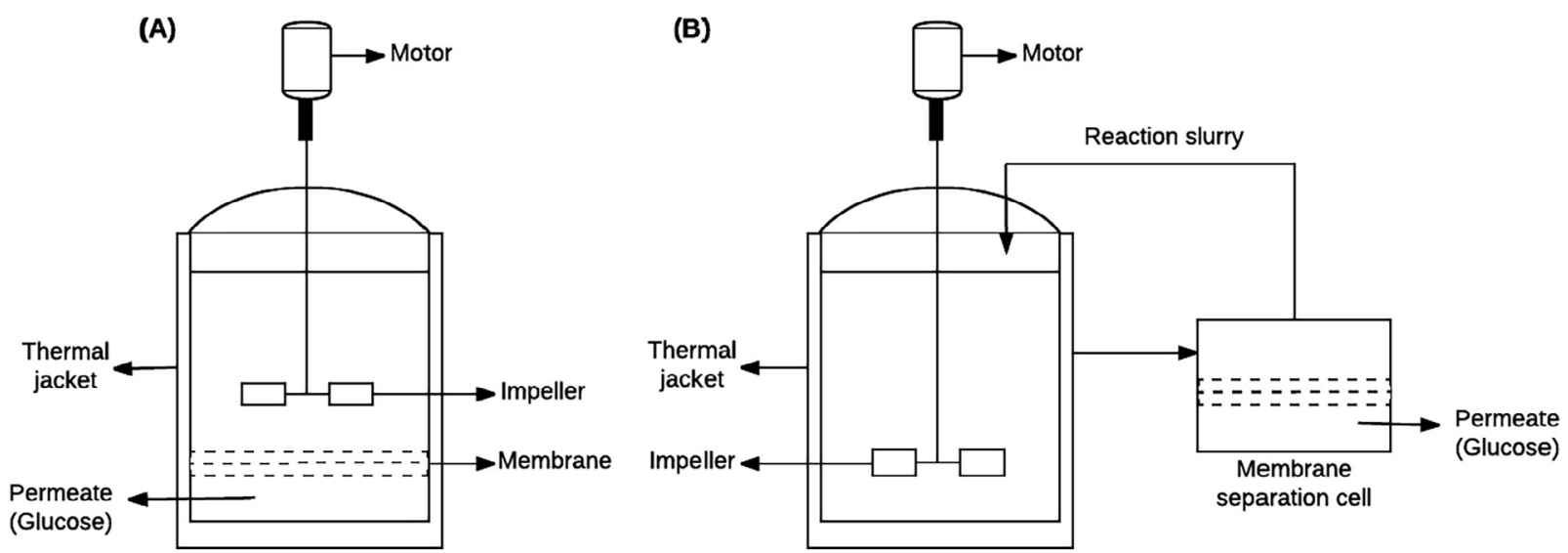

Fig. 6. Schematic representation of system configurations for membrane bioreactors (A) Integrated to reaction tank, (B) Separated from the reaction tank. Modified and adapted from I. Ohlson et al. [114] and N. Mameri et al. [117]. 


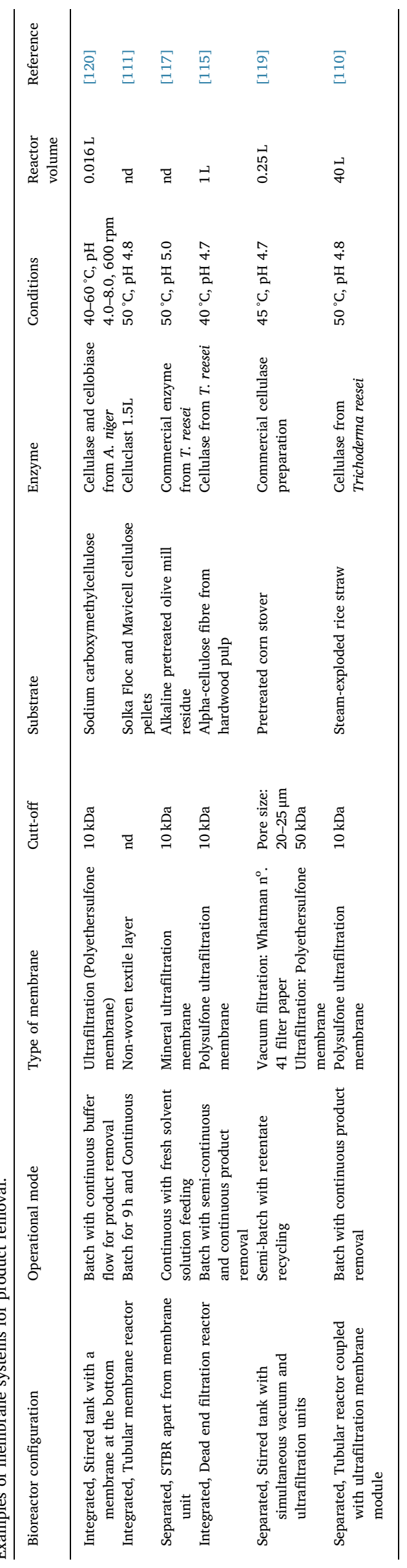

membrane surface acting as a secondary membrane that avoids the permeation of the desired compounds. Fouling effect depends on several factors, including the type of membrane, nature of solutes, hydrodynamic properties, operation conditions, and the interactions between the membrane and solids [127]. Enzymes tend to cause internal fouling of the membranes, because their size is similar to the membrane's pore size, remaining trapped into the membrane matrix and blocking the membrane pores [45,112,128]. Generally, ultrafiltration membranes undergo superficial fouling, while in microfiltration membranes pore blocking occurs in greater extent [129]. Therefore, it is important to consider an efficient membrane cleaning method to avoid undesired fouling by the accumulation of solid particles on the membrane surface. To avoid fouling of the semipermeable barrier different strategies have been proposed; some authors suggest the application of intense mixing to increase turbulence or higher transmembrane pressure as driving force. Also, backflushing of the membrane has been studied [111,130]. More recent investigations propose the use of electro-kinetic membrane cleaning where electrical pulses are applied in situ across the membrane to diminish the concentration polarization and thus avoid the fouling of the separation cell $[115,116]$. Furthermore, it has been proposed MBR's operation in cross-flow mode to prevent membrane fouling, which reduces permeate flux decline through the filtration process [131]. Nevertheless, the most promising alternative to avoid fouling in MBR is the application of a previous pretreatment of the material filtrate in order to remove solids that can potentially foul the semipermeable barrier $[45,130]$. Knutsen et al. [58] studied cellulase recovery by ultrafiltration. They evaluated the implementation of a sedimentation process before the ultrafiltration, with the aim to eliminate particles larger than $50 \mu \mathrm{m}$, obtaining little enzyme activity loss and higher permeate flux compared to the un-sedimented treatment, which reflect lesser membrane fouling with the pre-sedimented assays.

The rejection coefficient is an important parameter to determine the performance of the membrane unit. It determines the ability of the membrane to retain or reject a component of a solution [97]. The rejection coefficient $(R)$ is mathematically defined as described in equation (7). The rejection coefficient for end products takes a value of 0 because it is considered that the concentration of the end product in the permeate flow $\left(C_{p}\right)$ is equivalent to the concentration within the reaction vessel $\left(C_{r}\right)$ due to non-rejection of the product. On the other hand, the rejection coefficient for substrate and biocatalyst must be 1 due to the complete rejection of them [115].

$R=1-C_{p} / C_{r}$

Also, it is important to study the solute transport across the membrane in order to understand the phenomenon taking place inside of the separation unit. Solute transport is stimulated by a transmembrane chemical potential gradient according to diffusive or convective phenomena [97]. It involves mass transfer and fluid dynamics features [116]. Pinelo et al. [116] suggest the model developed by Jonsson et al. [132] as an alternative to describe the solute transport across the membrane in a bioreactor. The model combines the viscous flow and the frictional model, considering water and solute transportation through the pores of the membrane, and assuming that friction takes place among the solute and the membrane pore. The model relates the rejection coefficient to the properties of solute molecules, as expressed in equations (8), to define the separation efficiency of the membrane. The friction coefficient $(b)$ and the distribution factor $(K)$ are defined as a relation between the solute and the pore diameters (see equations (9) and (10)).

$1 /(1-R)=b / K+(1-b / K) \exp \left(-T_{0} \lambda J_{v} / \varepsilon D_{i}\right)$

$b=\frac{\left(A_{w} / A_{p}\right)_{\text {friction }}}{\left(A_{i} / A_{p}\right)_{\text {friction }}}$ 
$K=\frac{\left(A_{i} / A_{p}\right)_{\text {steric }}}{\left(A_{w} / A_{p}\right)_{\text {steric }}}$

However, it is important to mention that this model may not be applied when operated at certain conditions, including operation at high fluxes because it does not contemplate the increase of the concentration polarization [116].

Besides, the stirring speed of the impeller is a key factor in the operation of MBR, because it defines the mixing pattern and the hydrodynamics at the surface of the selective barrier, thus influencing the membrane's operation. Liu et al. [120] used a MBR consisting of a STBR reactor with an ultrafiltration membrane coupled to the base of the vessel to carry out the hydrolysis of sodium carboxymethylcellulose. They evaluated agitation ranging from $300 \mathrm{rpm}$ to $1200 \mathrm{rpm}$ and found out that the increase in the stirring speed leads to higher cellulose conversion, due to a better interfacial mass transfer in the reaction medium and a more efficient adsorption of the enzyme to the substrate [120]. In contrast, Gan et al. [115] reported that there is no significant effect of the stirring speed on the product yield. They studied the reducing sugar production in an integrated MBR using a bleached and pulverized cellulose fibre obtained from hardwood pulp and evaluated agitation speed between 50 and $90 \mathrm{rpm}$. The authors did not detect a significant relationship between cellulose conversion and stirring speed. Consequently, it can be inferred that the influence of the mixing speed in MBR is highly dependent on the range of the stirring speed evaluated, since in the latter case a small range of stirring speed has been evaluated.

2.2.2.3. Volume determination. To design a MBR it is necessary to consider the reaction kinetics involved in the bioprocess. Al-Zuhair et al. [34] studied the enzymatic hydrolysis of cellulose in a continuous STBR with $10 \mathrm{kDa}$ molecular weight cut-off flat sheet ultrafiltration membranes coupled to the vertical sides of the reaction vessel. The authors proposed the utilization of mass balances and reaction kinetics to determine the MBR volume, considering several assumptions, such as first order reaction, perfect mixing in the vessel and a specific desired percentage of cellulose conversion. The proposed mass balances are presented in the following equations. Specifically, equations (11) to (14) represent the mass balances of cellulose, cellobiose, glucose and, glucose through the membrane, respectively; where mass flow rates are correlated with the rates of conversion and the bioreactor volume $\left(V_{M B R}\right)$. Furthermore, equation (15) indicates the conversion of inlet cellulose into glucose.

$F_{C}=F_{C i}-r_{1} V_{M B R}$

$F_{B}=\left(r_{1}-r_{2}\right) V_{M B R}$

$F_{G}=r_{2} V_{M B R}-F_{P G}$

$F_{P G}=K_{m p}\left(G-G_{p}\right)$

$x=\left(F_{P G}+F_{G}\right) / F_{C i}$

Also, Al-Zuhair et al. [34] suggested the use of the mathematical reaction kinetic model described in equations (16) and (17) proposed by Philippidis et al. [133], where $r_{1}$ represents the conversion rate of cellulose to cellobiose, while $r_{2}$ indicates the conversion rate of cellobiose to glucose. The model considers the inhibition effect by cellobiose and glucose in the conversion of cellulose to cellobiose and then to glucose.

$$
\begin{aligned}
& r_{1}=\frac{k_{1} C}{1+B / K_{1 B}+G / K_{1 G}} \\
& r_{2}=\frac{k_{2} B}{K_{m}\left(1+G / K_{2 G}\right)+B}
\end{aligned}
$$

\subsection{Operation strategies}

As mentioned previously in Section 1.2.2, several strategies have been proposed to enhance enzymatic hydrolysis. The following sections describe the most common ones, as well as, give some examples of current researches that have adopted these strategies.

\subsubsection{Enzyme recycling}

Cellulase enzymes are expensive, which makes them one of the main challenges of enzymatic hydrolysis stage and of the bioethanol production process as a whole [134]. Therefore, it is necessary to look for alternatives to diminish the impact of enzyme costs. From this, the idea of recycling enzymes to ensure its efficient use arose. Enzyme recycling is considered an effective strategy to improve the cellulose bioconversion into glucose, but the enzymes must be stable to avoid their deactivation through numerous recycling cycles. Several cellulolytic enzymes proven to be stable enough to withstand recycling [135]. In lignocellulosic bioethanol production, there are three possible streams that can be considered for enzyme recycling: the effluent of enzymatic hydrolysis, the fermentation broth and, the stillage [45].

Tan et al. [134] proposed a continuous system that consisted in a column bioreactor connected to a $10 \mathrm{kDa}$ membrane unit, so that the effluent from the hydrolysis reaction was transferred to the membrane cell which allowed the low molecular weight sugars permeate through it, while the substrate and enzymes were retained and continuously recycled to the column reactor. The authors obtained higher percentage of cellulose conversion with this strategy than in the batch reactor. It is important to mention that several MBR investigations previously described in Section 2.2.2, apply enzyme recycling to take advantage of unhydrolyzed cellulose and the enzyme on the retentate.

Rodrigues et al. [135] studied another alternative of enzyme recycling. There are certain substances that can be used to remove cellulase enzymes from lignocellulosic residues, such as, surfactants, urea, alkali, polyethylene glycol, among other. The strategy proposed by the authors, consisted in the recovery of the enzymes adsorbed on the solid phase of the enzymatic hydrolysis through alkaline washing, which is reported as the method with the lowest enzyme deactivation. In this work, Rodrigues et al. [135], used different commercial enzymes cocktails and concluded that the enzyme recycling must be studied specifically for each formulation, because the enzyme tends to behave differently in each of them.

\subsubsection{High solid loadings}

In enzymatic hydrolysis, insoluble solid loadings between 12 and $15 \%(\mathrm{w} / \mathrm{w})$ are specified as the highest limit that allow an adequate mixing of the phases in conventional STBR; higher solid levels hinder mass transfer phenomena because the slurry viscosity increases becoming a non-Newtonian fluid that diminishes the saccharification efficiency $[95,136]$. The enzymatic saccharification experiments performed above 15\% (w/w) solid loading are known as high solids loading enzymatic hydrolysis $[1,137]$.

As mentioned in Section 1.2.2, enzymatic hydrolysis of lignocellulosic biomass at high solid loadings increases the glucose yield and therefore the overall bioethanol production. Additionally, high solids loading enzymatic hydrolysis has some economic benefits, such as lower capital investment due the smaller reactor size, reduced fermentation costs due to maximized glucose concentrations and, diminished water consumption, which entails lower water treatment costs $[138,139]$. However, it is well documented that an increase in solid content produces mixing difficulties, thus, several bioreactor proposals have been made to overcome the mass transfer problems, including horizontal rotating tubular bioreactors and different impeller configurations in STBR [74,140]. In the design of a bioreactor for high solids loading enzymatic hydrolysis, the most important parameters and variables to be considered are: mixing performance, energy consumption and enzyme utilization efficiency [95]. 
Numerous studies have demonstrated that horizontally orientated bioreactors are more effective for the development of enzymatic saccharification at high solids loadings, because it takes advantage of gravity (free fall) to induce mixing, as well as it reduces particle settling and hydrolysis product accumulation in certain zones of the bioreactor $[139,141]$. Moreover, horizontal bioreactors have the advantage of requiring lower energy supply than STBR and, being easy to scale up [139]. Fig. 7 presents a typical horizontal rotating tubular bioreactor for high solids loading enzymatic saccharification.

Du et al. [95] investigated the enzymatic hydrolysis of pretreated corn stover at solid loadings above $20 \%(\mathrm{w} / \mathrm{w})$ in two bioreactors: a horizontal rotating tubular bioreactor with fixed inner blades and a vertical STBR with double helical impeller. The results obtained showed that the cellulose conversion was higher in horizontal bioreactors than in STBR under the same conditions.

Additionally, Du et al. [74] studied three different strategies to overcome the mass transfer limitations in the enzymatic hydrolysis of delignified corncob residue at high solid loadings: pre-mixing, fed-batch and horizontal rotating tubular bioreactor. The results showed that the horizontal mixing was the most effective approach, to overcome the mass transfer limitations existing in high solids enzymatic hydrolysis. The horizontal rotating tubular bioreactor presented an increased liquefaction degree and an improved glucose production rate, at the initial phase of the saccharification at high solid loadings. Moreover, higher glucose yield was achieved with this strategy with a cellulose conversion to glucose of $63.8 \%$.

Other researchers have used vertical stirred bioreactors with diverse impeller configurations to guarantee adequate contact among cellulase and substrate, such as peg-mixer [101], anchor impeller [104] and, double helical impeller [95]. Table 2 presents an overview of different bioreactor configurations for enzymatic hydrolysis at high solid loadings.

\section{Future promising bioreactors for enzymatic hydrolysis}

There are other types of reactors known as pneumatically agitated bioreactors, which usually employ gas to induce the mixing in the reaction vessel. The gas mixture, normally air, is introduced at the bottom of the bioreactor via nozzles, perforated plates, or a sparger ring, which promote the liquid circulation, without the need for moving mechanical parts. In pneumatically agitated bioreactors the gas-liquid contact is an important aspect. The gas is mixed with the liquid phase during the mass transfer process and provide energy through the gas expansion [142].

The two main types of pneumatically agitated bioreactors are gaslift, also known as airlift, and bubble column. Pneumatically agitated bioreactors present several advantages over other multiphase reactors, including low shear stress, simple design, no mechanically moving parts, low energy supply, good mass transfer properties and, low construction and operation costs [143-145].

Even though this type of bioreactors has still not been used for enzymatic hydrolysis, they represent a promising configuration for the development of enzymatic saccharification, due to the lower energy consumption since they do not require mechanical stirrer to agitate the system. Additionally, pneumatically agitated bioreactors, specifically bubble column bioreactors, gas-lift and fluidized bed bioreactors have been widely used in three-phase systems (gas-liquid-solid) in chemical and biological processes in industry, for example, in cellulolytic and hemicellulolytic enzyme production and, environmental pollution control [145-147]. In three-phase systems the gas comes into contact simultaneously with the liquid and solid phases. Multiphase systems in airlift bioreactors present certain advantages, such as lower energy consumption, controlled mixing, reduced shear rate and good solid suspension efficiency. It is also reported that the three-phase system airlift bioreactors have advantages over bubble column bioreactors regarding to the lower use of energy when working with high solids loadings, due to the presence of a liquid circulation loop resulting from the density difference among downcomer and riser regions [148]. That is an important issue when using pneumatically agitated bioreactor in enzymatic hydrolysis, because a proper solid-liquid mixing must be ensured to achieve higher glucose yields.

For the design of a three-phase gas-lift bioreactor, it is necessary to consider certain parameters, such as the liquid circulation speed, because it has a crucial effect on the recirculation bubble and the distribution of gas and solids holdups [146,148]. Also, in the presence of solid phase in these types of bioreactors makes the studies of the hydrodynamics and oxygen mass transfer very important for the evaluation of the bioreactor performance and operation. The parameters such as, volumetric oxygen transfer coefficient and gas holdup are heavily influenced by solids loading, air flow rate, temperature, liquid properties, column diameter and sparger design, as well as the size and density of solid particles in a three-phase system [145,149].

\subsection{Bubble column bioreactors}

Bubble column bioreactors are classified as multiphase reactors. They consist of a vertical cylindrical vessel, where the application of a gas bubbling agitates the liquid phase or the liquid-solid suspension $[145,150]$. The gas is injected at the bottom of the column through a spray or a set of nozzles in form of jets, allowing the gas to enter the liquid phase and break up into bubbles. The holes in the distributer are designed to provide output speeds of $100-300 \mathrm{~m} \mathrm{~s}^{-1}$. However, the size of the hole does not completely define the bubble size, as it also depends on the physical properties of the liquid phase and the gas flow rate. In laboratory scale, porous glass disc or sintered metal plate are occasionally used as gas distributers. Typically, bubble column bioreactors are constructed with a height/diameter ratio ranging from 1.5 to 20 . There are several variables involved in the design of a bubble column bioreactor, however, the superficial gas velocity is one of the most important due to its relationship with other important variables, such as gas hold up, interfacial area and mass transfer coefficient [96].

Fig. 8 shows a typical configuration of bubble column bioreactors, where the gas is injected at the bottom of the vessel and the bubbles are dispersed throughout the reactor. Besides, the columns may have internal coils for heat transfer and baffles to reduce axial mixing $[96,142]$.

\subsection{Gas-lift bioreactors}

Gas-lift bioreactors consist of a vessel divided into two cameras, as shown in Fig. 9, one of them contains a gas sparger at the bottom thereof, which provides for bubbling into the system, while the other zone is ungassed. The different gas holdup between the two sections, provokes the well-known gas-lift action, which consists on the movement of the fluid by the difference of densities among the regions. The camera with the upflowing phases is called riser and the one with the downflowing phases is the downcomer, which are interconnected at the top and bottom of the bioreactor [144].

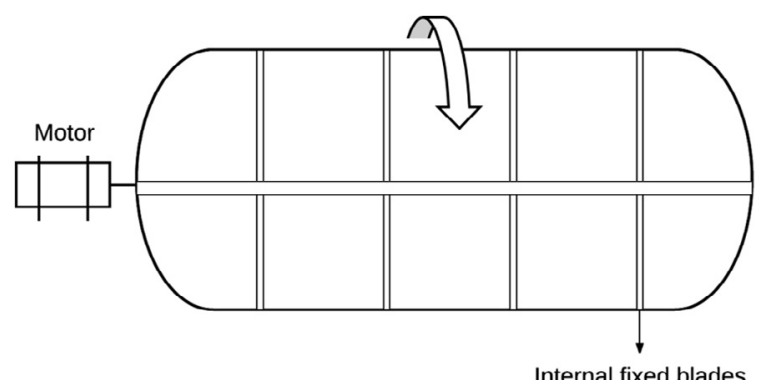

Fig. 7. Horizontal rotating tubular bioreactor with fixed inner blades. Modified and adapted from Jørgensen et al. [141] and Du et al. [95]. 


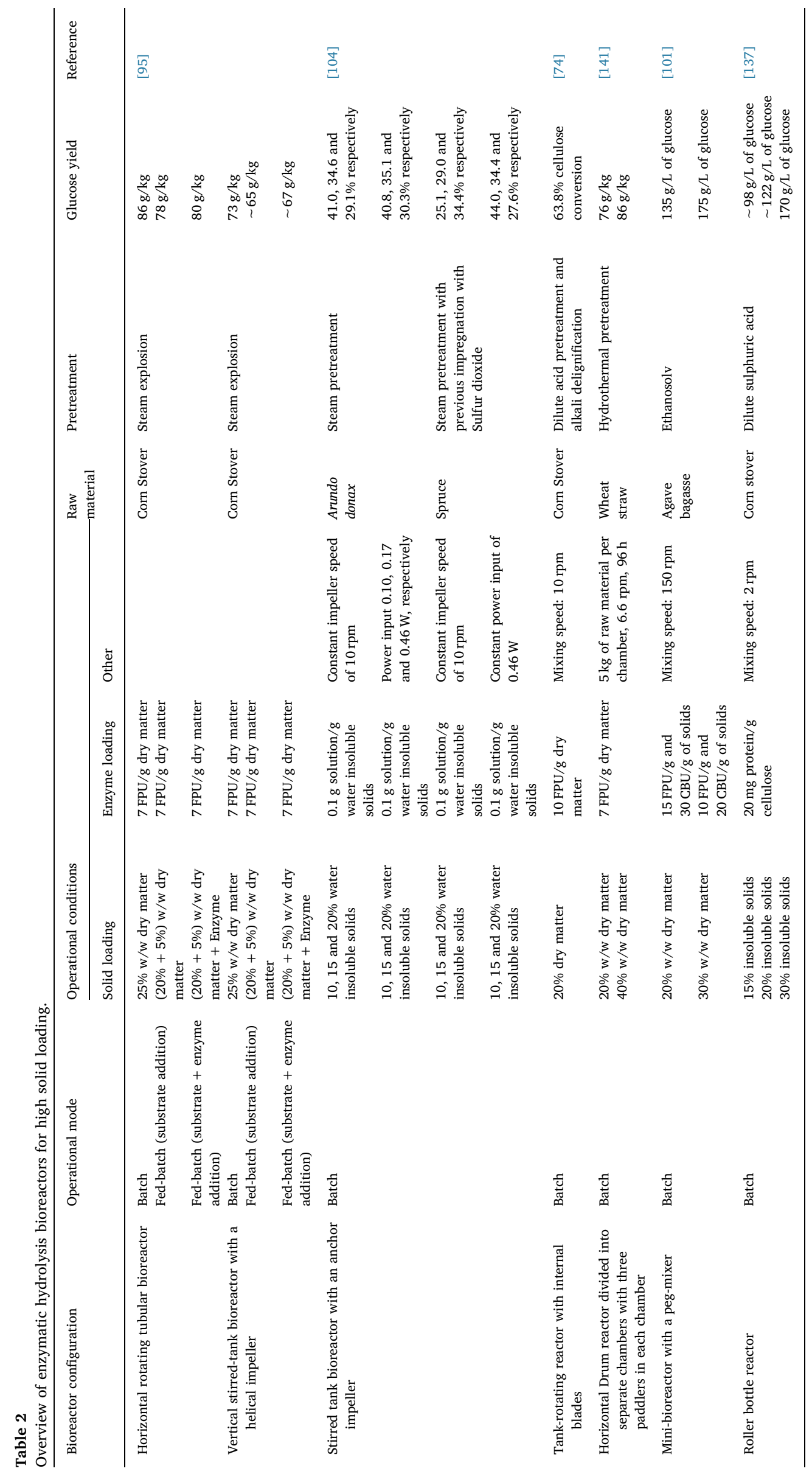




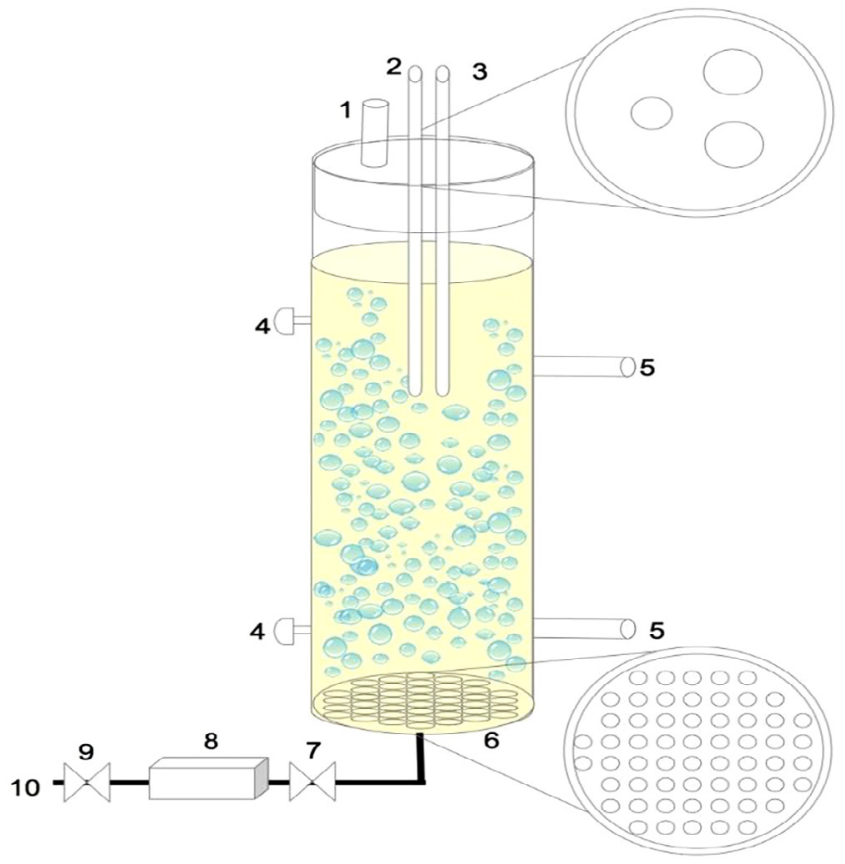

Fig. 8. Bubble column bioreactor (1. Gas outlet, 2. pH electrode with temperature meter, 3. Oxygen probe, 4. Sample collection, 5. Translators pressure, 6. Sparger, 7. Gas filter, 8. Rotameter, 9. Pressure regulator and 10. Gas inlet). Modified and adapted from Esperança et al. [145].

Generally, in the riser, the gas velocity is greater than the liquid velocity, except when the system flow is homogeneous, where the gas and the liquid phases flow at the same velocity, specifically when the bubble size is very small. On the other hand, in the downcomer, the liquid descends and may entrap bubbles in it, which happens when the liquid velocity is higher than the upward velocity of the bubbles. However, when the input gas flow is slow, low liquid superficial velocity is produced, which allows the bubbles to be released at the top of the bioreactor, and the liquid phase, comes down the downcomer. When a higher gas flow is supplied, the liquid velocity increases and entraps larger bubbles, thus reducing the region available for the liquid flow [142]. A typical gas-lift bioreactor consists in two concentric cylinders as shown in Fig. 9.

There are other configurations of gas-lift bioreactors that have been developed and studied over the years. These bioreactors are divided into two groups. The internal loop gas-lift bioreactor that differs from the bubble column in the existence of an internal baffle or, a concentric draft-tube that divides the bioreactor among a riser and a downcomer. On the other hand, the external loop gas-lift bioreactors, also known as outer loop gas-lift bioreactors, consist on two separate tubes that are interconnected at the top and the bottom [144]. This type of bioreactors is extensively used in bioprocesses because they are easy to build [151].

\subsection{Design parameters}

There are diverse parameters and variables that must be taken into account in the design of a bubble column or a gas-lift bioreactor, however, the most important ones are gas holdup and the volumetric mass transfer coefficient as they indicate the performance of the bioreactor [152]. In the following sections, an overview of these two parameters will be given.

\subsubsection{Gas holdup}

Gas holdup is a key variable for the characterization of the transport phenomena in bubble column and gas-lift bioreactors. It is defined as the volumetric fraction of gas in the gas-liquid dispersion [150]. Gas holdup is important to determine several parameters, such as the determination of the residence time of the gas in the liquid phase [152]. In the bubble column and gas-lift bioreactors, the gas holdup is mainly influenced by the superficial gas velocity in the vessel [144].

Gas holdup $\left(\varepsilon_{g}\right)$ is related to the gas flow rate in a proportional way, as mathematically expressed in equation (18), where $v_{b}$ represents the average bubble velocity and $V_{g}$ the superficial gas velocity [96].

$V_{g}=v_{b} \varepsilon_{g}$

In laboratory scale, a simplified equation is used to determine the gas holdup, which relates the aerated liquid height $\left(h_{a l}\right)$ with the original height $\left(h_{o l}\right)$ (see equation (19)).

$\varepsilon_{g}=1-\frac{h_{o l}}{h_{a l}}$

Equations (21) to (29) present a summary of mathematical expressions that are frequently used to determine the gas hold up in bubble column and airlift bioreactors, according to different variables indicated in Table 3. Specifically, equation (21) expresses gas hold up as an empirical relation between the volume of the liquid and the power input due to gas [153]. Equation (22) is an empirical expression obtained by Hikita et al. [154] for gas hold up in aqueous non-electrolyte solutions. In another study on bubble column bioreactors, Sada et al. [155] proposed to include the gas-liquid density ratio $\left(\rho_{g} / \rho_{l}\right)$ on the mathematical expression previously reported by Akita et al. [156] for the gas hold up calculation (see equations (23) and (24)). On the other hand, equation (25) correlates the gas hold up with the riser gas velocity $\left(U_{L r}\right)$ in a gas-lift bioreactor [157]. Prakash et al. [158] developed equation (26) to determine gas hold up considering the axial pressure difference $(\Delta P / \Delta H)$ through the height of a bubble column bioreactor. Equation (27) presents a mathematical expression to calculate gas hold up in newtonian fluids [159]. Ghosh et al. [160] used equation (28) for gas hold up determination, which relates the superficial gas velocity and the bubble rise velocity $\left(U_{b r}\right)$. In another investigation, Shah et al. [161] determined the gas hold up in a bubble column reactor as a function of Froude and Galileo numbers to describe the gas and liquid phases forces interactions (see equation (29)).

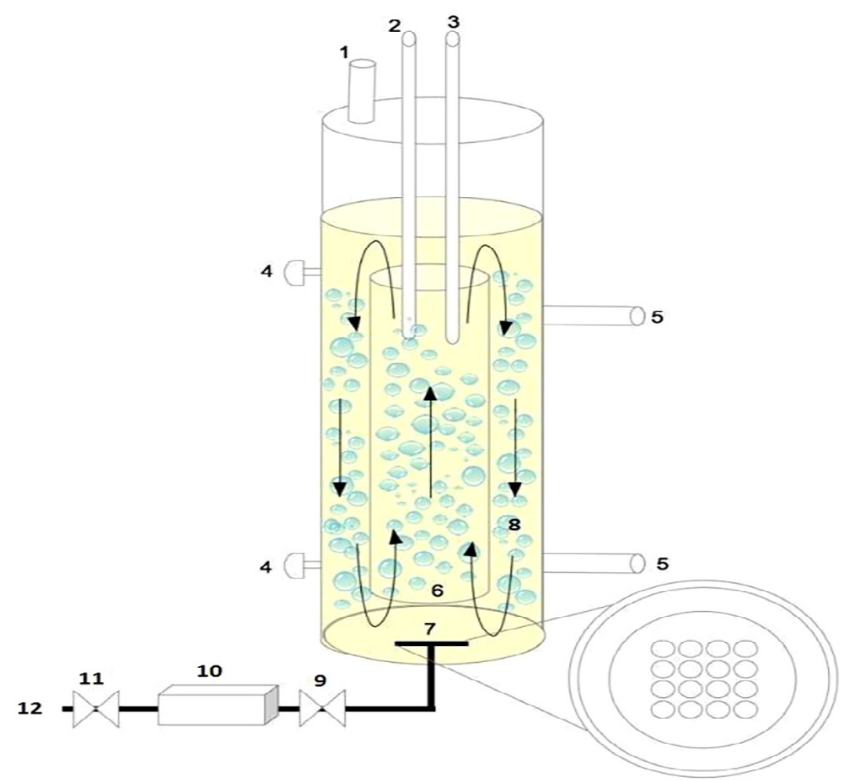

Fig. 9. Gas-lift bioreactor (1. Gas outlet, 2. $\mathrm{pH}$ electrode with temperature meter, 3. Oxygen probe, 4. Sample collection, 5. Translators pressure, 6. Riser, 7. Sparger, 8. Downcomer, 9. Gas filter, 10. Rotameter, 11. Pressure regulator and 12. Gas inlet). Modified and adapted from Chisti et al. [144] and Esperança et al. [145]. 
Table 3

Gas holdup for gas-liquid phase on bubble columns and gas-lift bioreactor.

\begin{tabular}{|c|c|c|c|c|}
\hline Equation & Bioreactors & Parameter & Equation & Reference \\
\hline (21) & Gas-lift & Volume of liquid $\left(V_{L}\right)$ & $\varepsilon_{g}=4.334 \times 10^{-3}\left(\frac{P_{G}}{V_{L}}\right)^{0.499}$ & [153] \\
\hline (22) & Bubble columns & Superficial gas velocity $\left(V_{g}\right)$ & $\varepsilon_{g}=0.505 V_{g}^{0.47}\left(72 / \sigma_{l}\right)^{2 / 3}\left(1 / \mu_{l}\right)^{0.05}$ & [154] \\
\hline (23) & Bubble columns & Superficial gas velocity $\left(V_{g}\right)$ & $\frac{\varepsilon_{g}}{\left(1-\varepsilon_{g}\right)^{4}}=0.32\left(g D_{c}^{2} \rho_{l} / \sigma_{l}\right)^{0.121}\left(g D_{c}^{3} / \mu_{k l}^{2}\right)^{0.086}\left(\rho_{g} / \rho_{l}\right)^{0.068}\left[V_{g} /\left(g D_{c}\right)^{1 / 2}\right]$ & [155] \\
\hline (24) & Bubble columns & Superficial gas velocity $\left(V_{g}\right)$ & $\frac{\varepsilon_{g}}{\left(1-\varepsilon_{g}\right)^{4}}=\frac{A\left(V_{g} \mu_{l} / \sigma_{l}\right)^{0.918}}{1+4.35\left(C_{S} / \rho_{S}\right)^{0.748}\left[\left(\rho_{S}-\rho_{l}\right) / \rho_{l}\right]^{0.881}} \frac{\left[g \mu_{l}^{4} /\left(\rho_{l} \sigma_{l}^{3}\right)\right]^{-0.252}}{\left(D_{c} V_{g} \rho_{l} / \mu_{l}\right)^{-0.168}}$ & [152] \\
\hline (25) & Gas-lift & Riser gas velocity $\left(U_{L r}\right)$ & $U_{L r}=\left[\frac{2 g h_{D}\left(\varepsilon_{r}-\varepsilon_{d}\right)}{K_{T} /\left(1-\varepsilon_{r}\right)^{2}+\left\{K_{B} /\left(1-\varepsilon_{d}\right)^{2}\right\}\left(A_{r} / A_{d}\right)^{2}}\right]^{0.5}$ & [157] \\
\hline (26) & Bubble columns & Pressure gradient along column height $(\Delta P / \Delta H)$ & $\varepsilon_{g}=1-\frac{1}{\rho_{l}+\varnothing_{S}\left(\rho_{S}-\rho_{l}\right)}(\Delta P / \Delta H)$ & [158] \\
\hline (27) & Bubble columns & Superficial gas velocity $\left(V_{g}\right)$ & $\frac{\varepsilon_{g}}{1+\varepsilon_{g}}=0.0625\left(\frac{V_{g}^{3}}{v_{l g}}\right)^{1 / 4}$ & [159] \\
\hline (28) & Bubble columns & Superficial gas velocity $\left(V_{g}\right)$ & $V_{g}^{2}=4 U_{b r}\left(g D_{c}\right)^{0.5} \varepsilon_{g}^{2.5}$ & {$[160]$} \\
\hline (29) & Bubble columns & Froude and Galileo number $\left(F r_{g} ; F r_{l} ; G_{a}\right)$ & $\varepsilon_{g}=0.072 F r_{g}^{0.224} F r_{l}^{-0.018} G a^{0.087}$ & {$[161]$} \\
\hline
\end{tabular}

\subsubsection{Mass transfer coefficient}

The volumetric mass transfer coefficient $\left(k_{L} a\right)$ is an important parameter in evaluating the performance of a bioreactor, because it allows determining the aeration efficiency and measuring the effects of operation variables on the dissolved oxygen supply [162]. Due to the importance of mass transfer in the chemical reactions that take place into the bioreactor, it is essential to estimate the $k_{L} a$ for the reactor design [150]. Volumetric mass transfer is one of the most commonly used parameters to scale up a process [142].

The mass transfer coefficient of the liquid phase can be calculated as, the change in the concentration of the liquid resulting from the absorption or extraction of a gas. Equation (20) presents the mass balance to determine the $k_{L} a$. It considers a pure gas; thus, no gas-phase resistance is contemplated, and the equilibrium concentration is considered constant. Also, the complete mixing in the liquid phase is assumed [96].

$\int \frac{d C_{L}}{C^{*}-C_{L}}=\ln \left(\frac{C^{*}-C_{0}}{C^{*}-C_{L}}\right)=k_{L} a t$

Equations from (30) to (34) presented on Table 4 correlate different parameters to determine the volumetric mass transfer coefficient in bubble column and gas-lift bioreactors, according to different authors. Fakhari et al. [163] used equation (30) to determine the volumetric mass transfer coefficient in an external loop gas-lift reactor, which includes the electrode response time. In another investigation, Choi et al. [164] adapted the overall mass transfer coefficient in an air-lift bioreactor to the equation (31) for a temperature of $20^{\circ} \mathrm{C}$ as reference. Moreover, equations (32) and (33) represent mathematical expressions to determine $k_{L} a$ considering the diameter in bubble column reactors $\left(D_{c}\right)$. Shah et al. [161] developed correlation shown in equation (34) to calculate the mass transfer coefficient using Froud and Galileo dimensionless numbers.

\section{Future perspectives}

Currently, enzymatic hydrolysis still represents a bottleneck of the production process of bioethanol, due to the high cost of enzymes and the generation of inhibitory compounds that diminish the glucose production efficiency. Therefore, further study should be made to ensure an adequate conversion of cellulose to glucose by considering the lignocellulosic biomass nature, because it determines the characteristics and the behavior of inhibitory compounds as well as the entire conversion process. At saccharification stage, bioreactors play an essential role to guarantee an adequate interaction between the enzymes and the substrate. Therefore, it is imperative to guarantee an optimal design of the bioreactor that improves the mass and heat transfers with low energy consumption, in order to increase the cellulose bioconversion and make the enzymatic hydrolysis a cost-effective process. Conventional bioreactors, such as STBR and MBR, have been widely used for the enzymatic hydrolysis processes. However, pneumatically agitated bioreactors, specifically bubble column and gas-lift configurations, are proposed as promising bioreactors for the development of enzymatic saccharification, with the advantage of low energy consumption due to not requiring mechanical mixing parts.

\section{Acknowledgement}

This work was financial supported by the Secretary of Public Education of Mexico - Mexican Science and Technology Council (SEPCONACYT) with the Basic Science Project-2015-01 (Ref. 254808), and the Energy Sustainability Fund 2014-05 (CONACYT-SENER), Mexican Centre for Innovation in Bioenergy (Cemie-Bio), and Cluster of

Table 4

Volumetric mass transfer coefficient for gas-liquid phase on bubble column and gas-lift bioreactor.

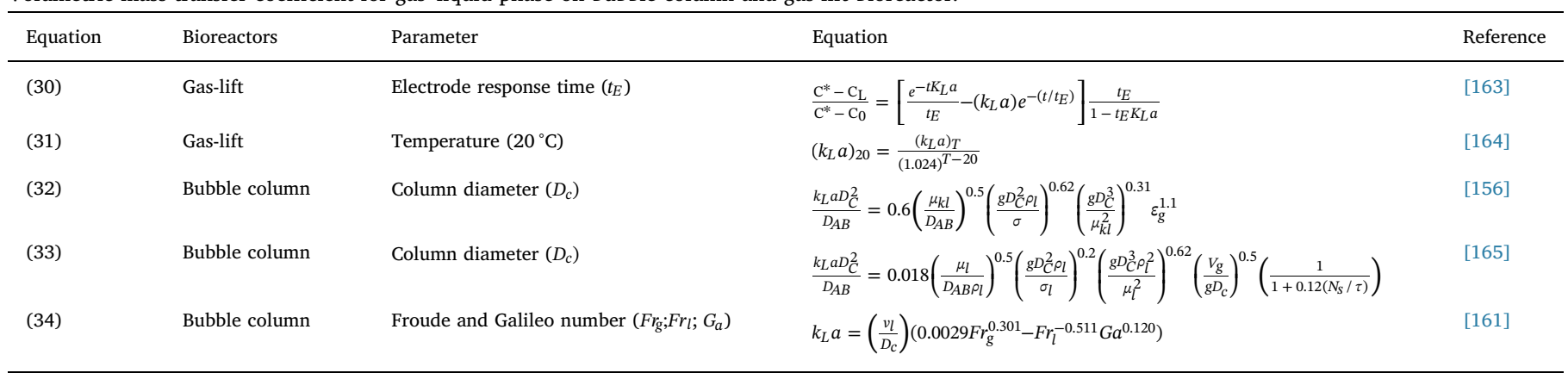


Bioalcohols (Ref. 249564). The author Marcela Pino also thanks the National Council for Science and Technology (CONACYT, Mexico) for her Master Fellowship support (grant number: 611312/452636).

\section{References}

[1] H.-Z. Chen, Z.-H. Liu, Enzymatic hydrolysis of lignocellulosic biomass from low to high solids loading, Eng. Life Sci. (2016) 1-11.

[2] H.B. Aditiya, T.M.I. Mahlia, W.T. Chong, H. Nur, A.H. Sebayang, Second generation bioethanol production: a critical review, Renew. Sustain. Energy Rev. 66 (2016) 631-653.

[3] H.A. Ruiz, R.M. Rodríguez-Jasso, B.D. Fernandes, A.A. Vicente, J.A. Teixeira, Hydrothermal processing, as an alternative for upgrading agriculture residues and marine biomass according to the biorefinery concept: a review, Renew. Sustain. Energy Rev. 21 (2013) 35-51.

[4] S. Fahd, G. Fiorentino, S. Mellino, S. Ulgiati, Cropping bioenergy and biomaterials in marginal land: the added value of the biorefinery concept, Energy 37 (2012) 79-93.

[5] A. Aguilar-Reynosa, A. Romaní, R.Ma. Rodríguez-Jasso, C.N. Aguilar, G. Garrote, H.A. Ruiz, Microwave heating processing as alternative of pretreatment in secondgeneration biorefinery: an overview, Energy Convers. Manage. 136 (2017) 50-65.

[6] H.A. Ruiz, M.A. Cerqueira, H.D. Silva, R.M. Rodríguez-Jasso, A.A. Vicente, J.A. Teixeira, Biorefinery valorization of autohydrolysis wheat straw hemicellulose to be applied in a polymer-blend film, Carbohydr. Polym. 92 (2013) 2154-2162.

[7] M. Balat, Global bio-fuel processing and production trends, Energy Explor. Exploit. 25 (2007) 195-218.

[8] I. Barrera, M.A. Amezcua-Allieri, L. Estupiñan, T. Martínez, J. Aburto, Technical and economical evaluation of bioethanol production from lignocellulosic residues in Mexico: case of sugarcane and blue agave bagasses, Chem. Eng. Res. Des. 107 (2016) 91-101.

[9] F. Cherubini, The biorefinery concept: using biomass instead of oil for producing energy and chemicals, Energy Convers. Manage. 51 (2010) 1412-1421.

[10] A. Scheidel, A.H. Sorman, Energy transitions and the global land rush: ultimate drivers and persistent consequences, Glob. Environ. Change 22 (2012) 588-595.

[11] R. Liguori, V. Ventorino, O. Pepe, V. Faraco, Bioreactors for lignocellulose conversion into fermentable sugars for production of high added value products, Appl. Microbiol. Biotechnol. 100 (2016) 597-611.

[12] S. Haghighi Mood, A. Hossein Golfeshan, M. Tabatabaei, G. Salehi Jouzani, G.H. Najafi, M. Gholami, M. Ardjmand, Lignocellulosic biomass to bioethanol, a comprehensive review with a focus on pretreatment, Renew. Sustain. Energy Rev 27 (2013) 77-93.

[13] H.M.N. Iqbal, G. Kyazze, T. Keshavarz, Advances in the valorization of lignocellulosic materials by biotechnology: an overview, BioResources 8 (2013) 3157-3176.

[14] H.A. Ruiz, A. Martínez, W. Vermerris, Bioenergy potential, energy crops, and biofuel production in Mexico, Bioenergy Res. 9 (2016) 981-984.

[15] M. Michelin, H.A. Ruiz, D.P. Silva, D.S. Ruzene, J.A. Teixeira, Cellulose from lignocellulosic waste, Polysaccharides (2014) 1-33.

[16] H. Zabed, J.N. Sahu, A.N. Boyce, G. Faruq, Fuel ethanol production from lignocellulosic biomass: an overview on feedstocks and technological approaches, Renew. Sustain. Energy Rev. 66 (2016) 751-774.

[17] K. Karimi, Lignocellulose-based bioproducts, 2015. doi: 10.1007/978-3-31914033-9.

[18] J. Moncada, J.A. Tamayo, C.A. Cardona, Integrating first, second, and third generation biorefineries: incorporating microalgae into the sugarcane biorefinery, Chem. Eng. Sci. 118 (2014) 126-140.

[19] F. Saladini, N. Patrizi, F.M. Pulselli, N. Marchettini, S. Bastianoni, Guidelines for emergy evaluation of first, second and third generation biofuels, Renew. Sustain. Energy Rev. 66 (2016) 221-227.

[20] G. Dragone, B. Fernandes, A. Vicente, J. Teixeira, Third generation biofuels from microalgae, Curr. Res. Technol. Educ. Top. Appl. Microbiol. Microb. Biotechnol. (2010) 1355.

[21] J. Velazquez-Lucio, R.M. Rodríguez-Jasso, L.M. Colla, A. Sáenz-Galindo, D.E. Cervantes-Cisneros, C.N. Aguilar, B.D. Fernandes, H.A. Ruiz, Microalgal biomass pretreatment for bioethanol production: a review, Biofuel Res. J. 5 (2018) 780-791.

[22] D. Chiaramonti, M. Prussi, S. Ferrero, L. Oriani, P. Ottonello, P. Torre, F. Cherchi, Review of pretreatment processes for lignocellulosic ethanol production, and development of an innovative method, Biomass Bioenergy 46 (2012) 25-35.

[23] P. Sannigrahi, A.J. Ragauskas, Fundamentals of biomass pretreatment by fractionation, Aqueous Pretreat. Plant Biomass Biol. Chem. Convers. Fuels Chem. (2013) 201-222.

[24] B. Yang, C.E. Wyman, Pretreatment: the key to unlocking low-cost cellulosic ethanol, Biofuels Bioprod. Biorefining 2 (2008) 26-40.

[25] F. Talebnia, D. Karakashev, I. Angelidaki, Production of bioethanol from wheat straw: an overview on pretreatment, hydrolysis and fermentation, Bioresour. Technol. 101 (2010) 4744-4753.

[26] Y. Zheng, J. Zhao, F. Xu, Y. Li, Pretreatment of lignocellulosic biomass for enhanced biogas production, Prog. Energy Combust. Sci. 42 (2014) 35-53.

[27] P. Kumar, D.M. Barrett, M.J. Delwiche, P. Stroeve, Methods for pretreatment of lignocellulosic biomass for efficient hydrolysis and biofuel production, Ind. Eng. Chem. Res. 48 (2009) 3713-3729.

[28] D.C. Nieves, H.A. Ruiz, L.Z. de Cárdenas, G.M. Alvarez, C.N. Aguilar, A. Ilyina,
J.L. Martínez Hernández, Enzymatic hydrolysis of chemically pretreated mango stem bark residues at high solid loading, Ind. Crops Prod. 83 (2016) 500-508.

[29] P. Alvira, E. Tomás-Pejó, M. Ballesteros, M.J. Negro, Pretreatment technologies for an efficient bioethanol production process based on enzymatic hydrolysis: a review, Bioresour. Technol. 101 (2010) 4851-4861.

[30] E. Zanuso, A.A. Lara-Flores, D.L. Aguilar, J. Velazquez-Lucio, C.N. Aguilar, R.M. Rodríguez-Jasso, H.A. Ruiz, Kinetic Modeling, Operational Conditions, and Biorefinery Products from Hemicellulose: Depolymerization and Solubilization During Hydrothermal Processing, in: H.A. Ruiz, M. Hedegaard Thomsen, H.L. Trajano (Eds.), Hydrothermal Process. Biorefineries Prod. Bioethanol High AddedValue Compd. Second Third Gener. Biomass, Springer International Publishing, Cham, 2017, pp. 141-160. doi: 10.1007/978-3-319-56457-9_5.

[31] G. Brodeur, E. Yau, K. Badal, J. Collier, K.B. Ramachandran, S. Ramakrishnan, Chemical and physicochemical pretreatment of lignocellulosic biomass: a review, Enzyme Res. 2011 (2011) e787532.

[32] M. Nikzad, K. Movagharnejad, F. Talebnia, Comparative study between neura network model and mathematical models for prediction of glucose concentration during enzymatic hydrolysis, Int. J. Comput. Appl. 56 (2012) 43-48.

[33] G.P. Maitan-Alfenas, E.M. Visser, V. ria M. Guimarães, Enzymatic hydrolysis of ignocellulosic biomass: converting food waste in valuable products, Curr. Opin. Food Sci. 1 (2015) 44-49.

[34] S. Al-Zuhair, M. Al-Hosany, Y. Zooba, A. Al-Hammadi, S. Al-Kaabi, Development of a membrane bioreactor for enzymatic hydrolysis of cellulose, Renew. Energy 56 (2013) 85-89.

[35] E. Palmqvist, B. Hahn-Hagerdal, Fermentation of lignocellulosic hydrolyzates. II: inhibitors and mechanisms of inhibition, Bioresour. Technol. 74 (2000) 25-33.

[36] S. Coseri, Cellulose: to depolymerize... or not to? Biotechnol. Adv. (2017).

[37] H.A. Ruiz, A.A. Vicente, J.A. Teixeira, Kinetic modeling of enzymatic saccharification using wheat straw pretreated under autohydrolysis and organosolv process, Ind. Crops Prod. 36 (2012) 100-107.

[38] C.T. Tsai, R. Morales-Rodriguez, G. Sin, A.S. Meyer, A dynamic model for cellulosic biomass hydrolysis: a comprehensive analysis and validation of hydrolysis and product inhibition mechanisms, Appl. Biochem. Biotechnol. 172 (2014) $2815-2837$.

[39] Y.H.P. Zhang, L.R. Lynd, Toward an aggregated understanding of enzymatic hydrolysis of cellulose: noncomplexed cellulase systems, Biotechnol. Bioeng. 88 (2004) 797-824.

[40] A. Limayem, S.C. Ricke, Lignocellulosic biomass for bioethanol production: current perspectives, potential issues and future prospects, Prog. Energy Combust. Sci. 38 (2012) 449-467.

[41] J.S. Van Dyk, B.I. Pletschke, A review of lignocellulose bioconversion using enzymatic hydrolysis and synergistic cooperation between enzymes-Factors affecting enzymes, conversion and synergy, Biotechnol. Adv. 30 (2012) 1458-1480.

[42] D.L. Aguilar, R.M. Rodríguez-Jasso, E. Zanuso, A.A. Lara-Flores, C.N. Aguilar, A. Sanchez, H.A. Ruiz, Operational strategies for enzymatic hydrolysis in a biorefinery, Biorefining Biomass Biofuels (2018), http://dx.doi.org/10.1007/978-3 319-67678-410.

[43] M.E. Himmel, S.Y. Ding, D.K. Johnson, W.S. Adney, M.R. Nimlos, J.W. Brady, T.D. Foust, Biomass recalcitrance: engineering plants and enzymes for biofuels production, Science (80-.) 315 (2007) 804-807.

[44] X. Zhang, Y.P. Zhang, Cellulases: characteristics, sources, production, and applications, in: Bioprocess. Technol. Biorefi Nery Sustain. Prod. Fuels, Chem. Polym., 2013, pp. 131-146. http://bioenergycenter.org/besc/publications/Zhang_ cellulases_yr7.pdf.

[45] H. Jørgensen, M. Pinelo, Enzyme recycling in lignocellulosic biorefineries, Biofuel Bioprod. Biorefining 11 (2017) 150-167.

[46] A. Várnai, M. Siika-Aho, L. Viikari, Carbohydrate-binding modules (CBMs) revisited: reduced amount of water counterbalances the need for CBMs, Biotechnol. Biofuels 6 (2013).

[47] J.K. Saini, A.K. Patel, M. Adsul, R.R. Singhania, Cellulase adsorption on lignin: a roadblock for economic hydrolysis of biomass, Renew. Energy 98 (2016).

[48] Z. Xiao, X. Zhang, D.J. Gregg, J.N. Saddler, Effects of sugar inhibition on cellulases and beta-glucosidase during enzymatic hydrolysis of softwood substrates, Appl. Biochem. Biotechnol. 113-116 (2004) 1115-1126.

[49] SIGMA-ALDRICH, Cellulase, enzyme blend, (n.d.). https://www.sigmaaldrich. $\mathrm{com} / \mathrm{catalog} /$ product/sigma/sae0020 ?lang $=$ es\&region $=$ MX\&gclid = EAIaIQobChMI66_tpsLX2QIVA5N-Ch2Jogh9EAAYASAAEgKbfvD_BwE (accessed March 6, 2018)

[50] S. Kanes, D. Forster, L. Wilkinson, Biofuels Outlook: Ethanol Margins Improve; Biodiesel Capacity Still Idle, (2010). http://www.scotiabank.com/ca/en/files/11/ 09/Biofuels_Outlook.pdf.

[51] G. Liu, J. Zhang, J. Bao, Cost evaluation of cellulase enzyme for industrial-scale cellulosic ethanol production based on rigorous Aspen Plus modeling, Bioprocess Biosyst. Eng. 39 (2016) 133-140.

[52] Y. Hong, A.-S. Nizami, M. Pour Bafrani, B.A. Saville, H.L. MacLean, Impact of cellulase production on environmental and financial metrics for lignocellulosic ethanol, Biofuels Bioprod. Biorefining 7 (2013) 303-313.

[53] E. Johnson, Integrated enzyme production lowers the cost of cellulosic ethanol, Biofuels Bioprod. Biorefining 10 (2016) 164-174.

[54] A. Aden, T. Foust, Technoeconomic analysis of the dilute sulfuric acid and enzymatic hydrolysis process for the conversion of corn stover to ethanol, Cellulose 16 (2009) 535-545.

[55] D. Klein-Marcuschamer, P. Oleskowicz-Popiel, B.A. Simmons, H.W. Blanch, The challenge of enzyme cost in the production of lignocellulosic biofuels, Biotechnol. Bioeng. 109 (2012) 1083-1087.

[56] F.K. Kazi, J.A. Fortman, R.P. Anex, D.D. Hsu, A. Aden, A. Dutta, 
G. Kothandaraman, Techno-economic comparison of process technologies for biochemical ethanol production from corn stover, Fuel 89 (2010) S20-S28.

[57] D. Humbird, R.E. Davis, L. Tao, C.M. Kinchin, D.D. Hsu, A. Aden, P. Schoen, J. Lukas, B. Olthof, M. Worley, D. Sexton, D. Dudgeon, Process design and economics for biochemical conversion of lignocellulosic biomass to ethanol, Renew. Energy 303 (2011) 147.

[58] J.S. Knutsen, R.H. Davis, Combined sedimentation and filtration process for cellulase recovery during hydrolysis of lignocellulosic biomass, Appl. Biochem. Biotechnol. - Part A Enzym. Eng. Biotechnol. 98-100 (2002) 1161-1172.

[59] A. Berlin, N. Girkes, A. Kurabi, M. Tu, D. Kilburn, J. Saddler, Weak lignin-binding enzymes a novel approach to improve activity of cellulases for hydrolysis of lignocellulosics, Appl. Biochem. Biotechnol. 121 (2005) 163-170.

[60] J. Zhang, M. Tang, L. Viikari, Xylans inhibit enzymatic hydrolysis of lignocellulosic materials by cellulases, Bioresour. Technol. 121 (2012) 8-12.

[61] X. Lu, X. Zheng, X. Li, J. Zhao, Adsorption and mechanism of cellulase enzymes onto lignin isolated from corn stover pretreated with liquid hot water, Biotechnol. Biofuels 9 (2016) 118.

[62] M. Li, Y. Pu, A.J. Ragauskas, Current understanding of the correlation of lignin structure with biomass recalcitrance, Front. Chem. 4 (2016) 1-8.

[63] M. Gruno, P. Väljamäe, G. Pettersson, G. Johansson, Inhibition of the Trichoderma reesei cellulases by cellobiose is strongly dependent on the nature of the substrate, Biotechnol. Bioeng. 86 (2004) 503-511.

[64] P. Andrić, A.S. Meyer, P.A. Jensen, K. Dam-Johansen, Reactor design for minimizing product inhibition during enzymatic lignocellulose hydrolysis: I. Significance and mechanism of cellobiose and glucose inhibition on cellulolytic enzymes, Biotechnol. Adv. 28 (2010) 308-324.

[65] B. Volynets, F. Ein-Mozaffari, Y. Dahman, Biomass processing into ethanol: pretreatment, enzymatic hydrolysis, fermentation, rheology, and mixing, Green Process Synth. (2016).

[66] R. Agrawal, A. Satlewal, K. Manali, M. Sujit, B. Biswajit, Investigating the enzymelignin binding with surfactants for improved saccharification of pilot scale pretreated wheat straw Investigating the Enzyme-Lignin Binding With Surfactants for Improved Saccharification of Pilot Scale Pretreated Wheat Straw Ruchi, Bioresour. Technol. (2016).

[67] A.C. Rodrigues, M. $\varnothing$. Haven, J. Lindedam, C. Felby, M. Gama, Celluclast and Cellic CTec2: saccharification/fermentation of wheat straw, solid-liquid partition and potential of enzyme recycling by alkaline washing, Enzyme Microb. Technol. 79-80 (2015) 70-77.

[68] M. Østergaard, J. Lindedam, M. Dan, M. Elleskov, A. Cristina, M. Gama, H. Jørgensen, C. Felby, Continuous recycling of enzymes during production of lignocellulosic bioethanol in demonstration scale, 159 (2015) 188-195.

[69] T.Y. Nguyen, C.M. Cai, R. Kumar, C.E. Wyman, Overcoming factors limiting highsolids fermentation of lignocellulosic biomass to ethanol, Proc. Natl. Acad. Sci. 201704652 (2017).

[70] Z. Kádár, Z. Szengyel, K. Réczey, Simultaneous saccharification and fermentation (SSF) of industrial wastes for the production of ethanol, Ind. Crops Prod. 20 (2004) 103-110.

[71] Y. Wang, X. Bian, L. Zhou, Simultaneous saccharification and fermentation (SSF) of cellulose from lignocelllulise for 2 nd bioethanol production: a review, 512-515 (2012) 464-467.

[72] A. Wingren, M. Galbe, G. Zacchi, Techno-economic evaluation of producing ethanol from softwood: comparison of SSF and SHF and identification of bottlenecks, Biotechnol. Prog. 19 (2003) 1109-1117.

[73] Z. Fan, C. South, K. Lyford, J. Munsie, P. van Walsum, L.R. Lynd, Conversion of paper sludge to ethanol in a semicontinuous solids-fed reactor, Bioprocess Biosyst. Eng. 26 (2003) 93-101.

[74] J. Du, Y. Cao, G. Liu, J. Zhao, X. Li, Y. Qu, Identifying and overcoming the effect of mass transfer limitation on decreased yield in enzymatic hydrolysis of lignocellulose at high solid concentrations, Bioresour. Technol. 229 (2017) 88-95.

[75] H. Teugjas, P. Väljamäe, Product inhibition of cellulases studied with 14C-labeled cellulose substrates, Biotechnol. Biofuels 6 (2013) 104.

[76] R. Purwadi, Continous ethanol production from dilute-acid hydrolyzates: detoxificacion and fermentation strategy, 2006.

[77] R. Navanietha Krishnaraj, J.-S. Yu, Bioenergy: Opportunities and Challenges, Apple Academy Press, Oakville, Ontario, 2016.

[78] H.A. Ruiz, D.P. Silva, D.S. Ruzene, L.F. Lima, A.A. Vicente, J.A. Teixeira, Bioethanol production from hydrothermal pretreated wheat straw by a flocculating Saccharomyces cerevisiae strain - effect of process conditions, Fuel 95 (2012) 528-536.

[79] A. Aguilar-reynosa, A. Romaní, R.M. Rodríguez-jasso, C.N. Aguilar, G. Garrote, H.A. Ruiz, Comparison of microwave and conduction-convection heating Biorefinery Group, Food Research Department, School of Chemistry, Autonomous Cluster of Bioalcohols, Mexican Centre for Innovation in Bioenergy (Cemie-Bio), CEB-Centre of Biological Engineeri, Bioresour. Technol. (2017).

[80] F. Avelino, H.A. Ruiz, C. Nogueira, E. Silvino, J.A. Teixeira, G. Ribeiro, D. Macedo, Comparison of delignified coconuts waste and cactus for fuel-ethanol production by the simultaneous and semi-simultaneous saccharification and fermentation strategies, 131 (2014) 66-76.

[81] O.A. Prado-Rubio, R. Morales-Rodríguez, P. Andrade-Santacoloma, H. HernándezEscoto, Process Intensification in Biotechnology Applications, in: Process Intensif. Chem. Eng., Springer International Publishing, Cham, 2016: pp. 183-219.

[82] R. Morales-Rodriguez, K.V. Gernaey, A.S. Meyer, G. Sin, A Mathematical model for simultaneous saccharification and co-fermentation (SSCF) of C6 and C5 sugars, Chin. J. Chem. Eng. 19 (2011) 185-191.

[83] K. Olofsson, M. Wiman, G. Lidén, Controlled feeding of cellulases improves con version of xylose in simultaneous saccharification and co-fermentation for bioethanol production, J. Biotechnol. 145 (2010) 168-175.

[84] J.-J. Zhong, 2.14 - Bioreactor Engineering, Compr. Biotechnol. second ed. 2 (2011) $165-177$.

[85] J.A. Teixeira, M.M. da Fonseca, Reactores Biológicos - Fundamentos e Aplicações, LIDEL (Brasil), Lisboa, 2007

[86] M. García-Aguirre, V.A. Sáenz-ÁLVARO, M.A. Rodríguez-Soto, F.J. VicenteMagueyal, E. Botello-ÁLVAREZ, H. Jiménez-Islas, C.M. Marcela, R. RicoMARTÍNEZ, J.L. Navarrete-BOLAÑOS, Strategy for biotechnological process design applied to the enzymatic hydrolysis of agave fructo-oligosaccharides to obtain fructose-rich syrups, J. Agric. Food Chem. 57 (2009) 10205-10210.

[87] G.T. Benz, Bioreactor design for chemical engineers, Am. Inst. Chem. Eng. (2011) 21-26.

[88] J. Zhang, D. Chu, J. Huang, Z. Yu, G. Dai, J. Bao, Simultaneous saccharification and ethanol fermentation at high corn stover solids loading in a helical stirring bioreactor, 105 (2010) 718-728.

[89] J.K.H., G.S. Ricardo Morales-Rodríguez, Marie Capron, Controlled fed-batch operation for improving cellulose hydrolysis in $2 \mathrm{G}$ bioethanol production, Elsevier B. V. (2010) 1-6. http://www.aidic.it/escape20/webpapers/304Morales-Rodriguez. pdf.

[90] R. Morales-Rodriguez, A.S. Meyer, K.V. Gernaey, G. Sin, Dynamic model-based evaluation of process configurations for integrated operation of hydrolysis and cofermentation for bioethanol production from lignocellulose, Bioresour. Technol. 102 (2011) 1174-1184.

[91] Y.-H. Chang, K.-S. Chang, C.-W. Huang, C.-L. Hsu, H.-D. Jang, Comparison of batch and fed-batch fermentations using corncob hydrolysate for bioethanol production, Fuel 97 (2012) 166-173.

[92] J.A. Asenjo, T. Yamane, Bioreactor Operation Modes, in: C. Press (Ed.), Bioreact Syst. Des., Marcel Dekker, Inc., New York, 1994, p. 648.

[93] V.B. Furlong, Automation of a reactor for enzymatic hydrolysis of sugar cane bagasse: computational intelligence-based adaptive control (2015).

[94] D.B. Hodge, M.N. Karim, D.J. Schell, J.D. McMillan, Model-based fed-batch for high-solids enzymatic cellulose hydrolysis, Appl. Biochem. Biotechnol. 152 (2009) 88-107.

[95] J. Du, F. Zhang, Y. Li, H. Zhang, J. Liang, H. Zheng, H. Huang, Enzymatic liquefaction and saccharification of pretreated corn stover at high-solids concentrations in a horizontal rotating bioreactor, Bioprocess Biosyst. Eng. 37 (2014) 173-181.

[96] P. Harriott, Chemical Reactor Design, 2003.

[97] G. Catapano, P. Czermak, R. Eibl, D. Eibl, R. Pörtner, Bioreactor design and scaleup, Cell Tissue React. Eng. (2009) 173-259.

[98] F. Garcia-Ochoa, V.E. Santos, E. Gomez, 2.15 - Stirred Tank Bioreactors, Compr. Biotechnol., second ed. 2 (2011) 179-198.

[99] L.J. Correâ, A.C. Badino, A.J.G. Cruz, Mixing design for enzymatic hydrolysis of sugarcane bagasse: methodology for selection of impeller configuration, Bioprocess Biosyst. Eng. 39 (2016) 285-294.

[100] A.A. Modenbach, S.E. Nokes, Enzymatic hydrolysis of biomass at high-solids loadings - a review, Biomass Bioenergy 56 (2013) 526-544.

[101] L. Caspeta, M.A. Caro-Bermúdez, T. Ponce-Noyola, A. Martinez, Enzymatic hydrolysis at high-solids loadings for the conversion of agave bagasse to fuel ethanol, Appl. Energy 113 (2014) 277-286.

[102] S.M.C. Peixoto, J.R. Nunhez, C.G. Duarte, Characterizing the flow of stirred vessels with anchor type impellers, Brazilian J. Chem. Eng. 17 (2000) 925-936.

[103] D. Carvajal, D.L. Marchisio, S. Bensaid, D. Fino, Enzymatic hydrolysis of lignocellulosic biomasses via CFD and experiments, Ind. Eng. Chem. Res. 51 (2012) $7518-7525$.

[104] B. Palmqvist, G. Lidén, Torque measurements reveal large process differences between materials during high solid enzymatic hydrolysis of pretreated lig nocellulose, Biotechnol. Biofuels 5 (2012) 57.

[105] B. Palmqvist, M. Wiman, G. Lidén, Effect of mixing on enzymatic hydrolysis of steam-pretreated spruce: a quantitative analysis of conversion and power consumption, Biotechnol. Biofuels 4 (2011) 10.

[106] A.W. Nienow, D. Miles, Impeller power numbers in closed vessels, Ind. Eng. Chem. Process Des. Dev. 10 (1971) 41-43.

[107] R.-K. Tan, W. Eberhard, J. Büchs, Measurement and characterization of mixing time in shake flasks, Chem. Eng. Sci. 66 (2011) 440-447.

[108] K. Van Riet, R. Van Der Lans, Mixing in Bioreactor Vessels, Elsevier B.V., second ed., 2011.

[109] K.W. Norwood, A.B. Metzner, Flow patterns and mixing rates in agitated vessels, AIChE J. 6 (1960) 432-437.

[110] S. Yang, W. Ding, H. Chen, Enzymatic hydrolysis of rice straw in a tubular reactor coupled with UF membrane, Process Biochem. 41 (2006) 721-725.

[111] K. Bélafi-Bakó, A. Koutinas, N. Nemestóthy, L. Gubicza, C. Webb, Continuous enzymatic cellulose hydrolysis in a tubular membrane bioreactor, Enzyme Microb. Technol. 38 (2006) 155-161.

[112] M.S. Mohd Sueb, J. Luo, A.S. Meyer, H. Jørgensen, M. Pinelo, Impact of the fouling mechanism on enzymatic depolymerization of xylan in different configurations of membrane reactors, Sep. Purif. Technol. 178 (2017) 154-162.

[113] P. Andrić, A.S. Meyer, P.A. Jensen, K. Dam-Johansen, Reactor design for minimizing product inhibition during enzymatic lignocellulose hydrolysis. II. Quantification of inhibition and suitability of membrane reactors, Biotechnol. Adv. 28 (2010) 407-425.

[114] I. Ohlson, G. Trägårdh, B. Hahn-Hägerdal, Enzymatic hydrolysis of sodium-hydroxide-pretreated sallow in an ultrafiltration membrane reactor, Biotechnol. Bioeng. 26 (1984) 647-653.

[115] Q. Gan, S.J. Allen, G. Taylor, Design and operation of an integrated membrane reactor for enzymatic cellulose hydrolysis, Biochem. Eng. J. 12 (2002) 223-229.

[116] M. Pinelo, G. Jonsson, A.S. Meyer, Membrane technology for purification of 
enzymatically produced oligosaccharides: molecular and operational features affecting performance, Sep. Purif. Technol. 70 (2009) 1-11.

[117] N. Mameri, F. Hamdache, N. Abdi, D. Belhocine, H. Grib, H. Lounici, D.L. Piron, Enzymatic saccharification of olive mill solid residue in a membrane reactor, J. Membr. Sci. 178 (2000) 121-130.

[118] T.K. Ghose, J.A. Kostick, A model for continuous enzymatic saccharification of cellulose with simultaneous removal of glucose syrup, Biotechnol. Bioeng. 12 (1970) 921-946.

[119] J.S. Knutsen, R.H. Davis, Cellulase retention and sugar removal by membrane ultrafiltration during lignocellulosic biomass hydrolysis, Appl. Biochem. Biotechnol. 113-116 (2004) 585-599.

[120] J. Liu, J. Lu, Z. Cui, Enzymatic hydrolysis of cellulose in a membrane bioreactor: assessment of operating conditions, Bioprocess Biosyst. Eng. 34 (2011) 525-532.

[121] J. Agustian, A.H. Kamaruddin, S. Bhatia, Enzymatic membrane reactors: the determining factors in two separate phase operations, J. Chem. Technol. Biotechnol. 86 (2011) 1032-1048.

[122] D.M.F. Prazeres, J.M.S. Cabral, Enzymatic membrane bioreactors and their applications, Enzyme Microb. Technol. 16 (1994) 738-750.

[123] M. Moronfade Ishola, Novel Application of Membrane Bioreactors, University of Borås, 2014. https://www.diva-portal.org/smash/get/diva2:877095/ FULLTEXT01.pdf.

[124] R. Abejón, M.P. Belleville, J. Sanchez-Marcano, Design, economic evaluation and optimization of enzymatic membrane reactors for antibiotics degradation in wastewaters, Sep. Purif. Technol. 156 (2015) 183-199.

[125] C. López, M.T. Moreira, G. Feijoo, J.M. Lema, Economic comparison of enzymatic reactors and advanced oxidation processes applied to the degradation of phenol as a model compound, Biocatal. Biotransformation 29 (2011) 344-353.

[126] A. Bick, L. Gillerman, Y. Manor, G. Oron, Economic assessment of an integrated membrane system for secondary effluent polishing for unrestricted reuse, Water (Switzerland) 4 (2012) 219-236.

[127] N. Singh, M. Cheryan, Fouling of a ceramic microfiltration membrane by corn starch hydrolysate, J. Membr. Sci. 135 (1997) 195-202.

[128] L. Giorno, L. Donato, S. Todisco, E. Drioli, Study of fouling phenomena in apple juice clarification by enzyme membrane reactor, Sep. Sci. Technol. 33 (1998) 739-756.

[129] A.D. Marshall, P.A. Munro, G. Trägårdh, The effect of protein fouling in microfiltration and ultrafiltration on permeate flux, protein retention and selectivity: a literature review, Desalination 91 (1993) 65-108.

[130] G.M. Rios, M.P. Belleville, D. Paolucci, J. Sanchez, Progress in enzymatic membrane reactors - a review, J. Membr. Sci. 242 (2004) 189-196.

[131] L. Giorno, E. Drioli, Biocatalytic membrane reactors: applications and perspectives, Trends Biotechnol. 18 (2000) 339-349.

[132] G. Jonsson, C.E. Boesen, Water and solute transport through cellulose acetate reverse osmosis membranes, Desalination 17 (1975) 145-165.

[133] G.P. Philippidis, T.K. Smith, C.E. Wyman, Study of the enzymatic hydrolysis of cellulose for production of fuel ethanol by the simultaneous saccharification and fermentation process, 41 (1993) 846-853.

[134] L.U.L. Tan, E.K.C. Yu, N. Campbell, J.N. Saddler, Column cellulose hydrolysis reactor: an efficient cellulose hydrolysis reactor with continuous cellulase recycling, Appl. Microbiol. Biotechnol. 25 (1986) 250-255.

[135] A.C. Rodrigues, M.Ø. Haven, J. Lindedam, C. Felby, M. Gama, Celluclast and cellic-CTec2: Saccharification/fermentation of wheat straw, solid-liquid partition and potential of enzyme recycling by alkaline washing, Enzyme Microb. Technol. 79-80 (2015) 70-77.

[136] D.B. Hodge, M.N. Karim, D.J. Schell, J.D. McMillan, Model-based fed-batch for high-solids enzymatic cellulose hydrolysis, Appl. Biochem. Biotechnol. 152 (2008) 88.

[137] C.M. Roche, C.J. Dibble, J.J. Stickel, Laboratory-scale method for enzymatic saccharification of lignocellulosic biomass at high-solids loadings, Biotechnol. Biofuels 2 (2009) 28.

[138] A. Mohagheghi, M. Tucker, K. Grohmann, C. Wyman, High solids simultaneous saccharification and fermentation of pretreated wheat straw to ethanol, Appl. Biochem. Biotechnol. Part A Enzym. Eng. Biotechnol. 33 (1992) 67-81.

[139] R.K. Dasari, K. Dunaway, R.E. Berson, A scraped surface bioreactor for enzymatic saccharification of pretreated corn stover slurries, Energy Fuels 23 (2009) $492-497$.

[140] K. Liu, J. Zhang, J. Bao, Two stage hydrolysis of corn stover at high solids content for mixing power saving and scale-up applications, Bioresour. Technol. 196 (2015) 716-720.
[141] H. Jørgensen, J. Vibe-Pedersen, J. Larsen, C. Felby, Liquefaction of lignocellulose at high-solids concentrations, Biotechnol. Bioeng. 96 (2007) 862-870.

[142] A.M. Mendoza Martnez, E.M. Escamilla Silv, Airlift Bioreactors: Hydrodynamics and Rheology Application to Secondary Metabolites Production, in: Mass Transf. Adv. Sustain. Energy Environ. Oriented Numer. Model., InTech, 2013.

[143] M. Bouaifi, G. Hebrard, D. Bastoul, M. Roustan, A comparative study of gas holdup, bubble size, interfacial area and mass transfer coefficients in stirred gas-liquid reactors and bubble columns, Chem. Eng. Process. 40 (2001) 97-111.

[144] M.Y. Chisti, M. Moo-Young, Airlift reactors: characteristics, applications and design considerations, Chem. Eng. Commun. 60 (1987) 195-242.

[145] M.N. Esperança, F.M. Cunha, M.O. Cerri, T.C. Zangirolami, C.S. Farinas, A.C. Badino, Gas hold-up and oxygen mass transfer in three pneumatic bioreactors operating with sugarcane bagasse suspensions, Bioprocess Biosyst. Eng. 37 (2014) 805-812.

[146] F. Wenge, Y. Chisti, M. Moo-young, A new method for the measurement of solids holdup in gas-liquid-solid three-phase systems, Ind. Eng. Chem. Res. 928-935 (1995).

[147] R.D. Pilz, D.C. Hempel, Mechanical stress on suspended particles in two- and three-phase airlift loop reactors and bubble columns, Chem. Eng. Sci. 60 (2005) 6004-6012.

[148] J. Klein, A.A. Vicente, J.A. Teixeira, Hydrodynamic considerations on optimal design of a three-phase airlift bioreactor with high solids loading, J. Chem. Technol. Biotechnol. 78 (2003) 935-944.

[149] A. Ferreira, P. Cardoso, J.A. Teixeira, F. Rocha, PH influence on oxygen mass transfer coefficient in a bubble column. Individual characterization of $\mathrm{kL}$ and a, Chem. Eng. Sci. 100 (2013) 145-152.

[150] N. Kantarci, F. Borak, K.O. Ulgen, Bubble column reactors, Process Biochem. 40 (2005) 2263-2283.

[151] M. Moo-Young, Y. Chisti, Considerations for designing bioreactors for shear-sensitive culture, Biotechnology, 6 (n.d.) 1291-1296.

[152] K. Koide, K. Horibe, H. Kawabata, S. Ito, Gas holdup and volumetric liquid-phase mass transfer coefficient in solid-suspended bubble column with draught tube, J. Chem. Eng. Japan. 18 (1985) 248-254.

[153] F.C. Rubio, J.L. Garcia, E. Molina, Y. Chisti, Axial inhomogeneities in steady-state dissolved oxygen in airlift bioreactors: predictive models, Chem. Eng. J. 84 (2001) 43-55.

[154] H. Hikita, H. Kikukawa, Liquid-phase mixing in bubble columns: effect of liquid properties, 8 (1974) 191-197.

[155] E. Sada, S. Katoh, H. Yoshii, T. Yamanishi, A. Nakanishi, Performance of the gas bubble column in molten salt systems, Ind. Eng. Chem. Process Des. Dev. 23 (1984) 151-154.

[156] K. Akita, F. Yoshida, Gas holdup and volumetric mass transfer coefficient in bubble columns. effects of liquid properties, Ind. Eng. Chem. Process Des. Dev. 12 (1973) 76-80.

[157] Y. Chisti, M. Moo-Young, Gas holdup behaviour in fermentation broths and other non-newtonian fluids in pneumatically agitated reactors, Chem. Eng. J. 39 (1988) 31-36.

[158] A. Prakash, A. Margaritis, H. Li, M.A. Bergougnou, Hydrodynamics and local heat transfer measurements in a bubble column with suspension of yeast, Biochem. Eng. J. 9 (2001) 155-163.

[159] Y. Kawase, S. Umeno, T. Kumagai, The prediction of gas hold-up in bubble column reactors: Newtonian and non-newtonian fluids, Chem. Eng. J. 50 (1992) 1-7.

[160] U.K. Ghosh, S.N. Upadhyay, Gas Holdup and Solid-Liquid Mass Transfer in Newtonian and non-Newtonian Fluids in Bubble Columns, 85 (2007) 825-832.

[161] M. Shah, A.A. Kiss, E. Zondervan, J. van der Schaaf, A.B. de Haan, Gas holdup, axial dispersion, and mass transfer studies in bubble columns, Ind. Eng. Chem. Res. 51 (2012) 14268-14278.

[162] F. Garcia-Ochoa, E. Gomez, Bioreactor scale-up and oxygen transfer rate in microbial processes: an overview, Biotechnol. Adv. 27 (2009) 153-176.

[163] M.E. Fakhari, M.K. Moraveji, R. Davarnejad, Hydrodynamics and mass transfer of oily micro-emulsions in an external loop airlift reactor, Chin. J. Chem. Eng. 22 (2014) 267-273.

[164] K.H. Choi, Y. Chisti, M. Moo-Young, Influence of the gas-liquid separator design on hydrodynamic and mass transfer performance of split-channel airlift reactors, $\mathrm{J}$. Chem. Technol. Biotechnol. 62 (1995) 327-332.

[165] I.-S. Suh, A. Schumpe, W.-D. Deckwer, W.-M. Kulicke, Gas-liquid mass transfer in the bubble column with viscoelastic liquid, Can. J. Chem. Eng. 69 (1991) 506-512. 